\title{
Heavy Metal Accrual in Soils and Crops Grown in the Peri Urban Areas of Jabalpur District of Madhya Pradesh, India using Geospatial Techniques
}

\author{
Balram Patel, Y. M. Sharma, G.S. Tagore*, G.D. Sharma and G. Halecha \\ Department of Soil Science and Agricultural Chemistry \\ Jawaharlal Nehru Krishi Vishwa Vidyalaya, Jabalpur, Madhya Pradesh, India \\ *Corresponding author
}

\section{Keywords}

Heavy metal,

Wastewater,

Transfer factor

clustering, GIS,

Peri urban areas of Jabalpur

Article Info

Accepted:

04 January 2019

Available Online:

10 February 2019

\section{A B S T R A C T}

The findings of present study suggested that the $\mathrm{pH}$ in soils neutral to slightly alkaline safe in electrical conductivity and low to medium in organic carbon content. Metals concentration was below the permissible limits at 200,400,600 and $800 \mathrm{~m}$, from both side of Omati Nala, in rainy and winter seasons, respectively. In water, $\mathrm{pH}$ ranged from 6.5 to 8.5 and $\mathrm{EC}$ under permissible range. However, $\mathrm{Pb}$ and $\mathrm{Cr}$ were comparatively higher than the Indian permissible limits. The concentration of $\mathrm{Ni}, \mathrm{Cr}$ and $\mathrm{Cd}$ in rice, wheat and Brinjal was higher than the limit given by WHO/Indian standard. The transfer factor was recorded for these metals in order of Brinjal, followed by the Spinach and Tomato. Result revealed that, the $\mathrm{pH}$ had negatively correlated with $\mathrm{OC}\left(\mathrm{r}=-0.252^{*}\right)$ and $\mathrm{Cr}\left(\mathrm{r}=-0.413^{* *}\right)$ in rainy season and similar relationship with EC $\left(\mathrm{r}=-0.601^{* *}\right), \mathrm{OC}\left(\mathrm{r}=-0.356^{* *}\right), \mathrm{Cd}\left(\mathrm{r}=-0.696^{* *}\right)$ and $\mathrm{Pb}\left(\mathrm{r}=-0.619^{* *}\right)$ in winter season. While, it had significant positive relationship with $\mathrm{Cr}(\mathrm{r}=0.304 * *)$. In winter season, the $\mathrm{EC}$ had positive and significant relationship with OC $\left(\mathrm{r}=0.239^{*}\right), \mathrm{Cd}\left(\mathrm{r}=0.366^{* *}\right)$ and $\mathrm{Pb}\left(\mathrm{r}=0.420^{* *}\right)$. In rainy and winter seasons, the $\mathrm{OC}$ showed significant positive relationship with $\mathrm{Ni}\left(\mathrm{r}=0.305^{* *}\right), \mathrm{Cd}\left(\mathrm{r}=0.279^{*}\right)$ and $\mathrm{Pb}$ $(\mathrm{r}=0.232 *)$ and $\mathrm{Cd}(\mathrm{r}=0.333 * *)$ and $\mathrm{Pb}(\mathrm{r}=0.240 *)$ respectively. The $\mathrm{Cd}$ in soil showed significant and positively related with $\mathrm{Ni}$ and $\mathrm{Cd}$ content in plant. Multivariate analysis results revealed that, the variables are correlated with two principal components in which 64.61 and $66.89 \%$ of the total variance were extracted in rainy and winter seasons respectively. The first component with 40.56 and $43.56 \%$ of variance comprises $\mathrm{Ni} \mathrm{Cd}$ and $\mathrm{Pb}$ and $\mathrm{pH}, \mathrm{EC}, \mathrm{OC}, \mathrm{Cd}$ and $\mathrm{Pb}$ with high loadings whereas; the second component contributes $\mathrm{pH}, \mathrm{EC}, \mathrm{OC}$ and $\mathrm{Cr}$ and $\mathrm{Ni}$ and $\mathrm{Cr}$ at 24.04 and $23.32 \%$ total variance in rainy and winter seasons, respectively. Clustering result grouped all sampling sites into nine and seven zones on the basis of spatial similarities among sites and differences among different groups in rainy and winter seasons, respectively. In rainy season, 1, 2, 3 and 4 zones were containing higher heavy metal concentrations than the zone 5,6,7,8 and 9 whereas in winter season, zone 1, 2, 3, 5 and 6 had higher concentrations of metals than the zone 4 and 7 . 


\section{Introduction}

The accumulation of heavy metals in agricultural soils is of increasing concern due to the food safety issues and potential health risks as well as its detrimental effects on soil ecosystems (Qishlaqi and Moore, 2007). These metals have peculiar characteristics one of they do not decay with time; they can be necessary or beneficial to plants at certain levels but can be toxic when exceeding specific thresholds; they are always present at a background level of non-anthropogenic origin, their input in soils being related to weathering of parent rocks and pedogenesis and they often occur as cations which strongly interact with the soil matrix, consequently, heavy metals in soils can become mobile as a result of changing environmental conditions. This situation is referred to as "chemical timing bomb" (Facchinelli et al., 2001).

Sources of these elements in soils mainly include natural occurrence derived from parent materials and human activities. The most important sources of heavy metals in the environment are the anthropogenic activities such as mining, smelting procedures, steel and iron industry, chemical industry, traffic, agriculture as well as domestic activities (Stihi et al., 2006;Jantschi et al., 2008). Chemical and metallurgical industries are the most important sources of heavy metals in soils (Schutze et al., 2007; Jantschi et al., 2008; Pantelica et al., 2008). Many reports have clearly documented the various human activities as a major cause for heavy metal contamination of the soil ecosystem which include mining processes, iron and steel industries, transportation, open disposal of waste, and use of inorganic fertilizers, pesticides on to the agricultural lands (Lado et al., 2008). Heavy metals contamination is more dominating in agricultural fields near by industrial areas because of large consumption of acidifying compounds and metal ores in industries that are released in form of untreated industrial effluents (Lin et al., 2002). Heavy metals present in industrial waste migrate via different sources e.g. water, soil sediments and air to nearby agricultural lands and thus become a source of heavy metal pollution in agricultural soils (De Vries et al., 2005).

Heavy metal contamination of soil is a far more serious problem than air or water pollution because heavy metals are usually tightly bound by the organic components in the surface layers of the soil. Consequently, the soil is an important geochemical sink which accumulates heavy metals quickly and usually depletes them very slowly by leaching into groundwater aquifers or bioaccumulating into plants (Infotox, 2000). Heavy metals can also be very quickly translocated through the environment by erosion of the soil particles to which they may adsorbed or bound and redeposited elsewhere. Irrigation of agricultural land with wastewater leads to the accumulation of heavy metals in soil (Chandra and Kulsheshtha, 2004; Tung et al., 2009; Jan et al., 2010). Once deposited on the soil certain metals such lead and chromium may be virtually permanent (Okeyode and Moshood, 2010).

Heavy metal pollution of soil enhance plant uptake causing accumulation in plant tissues and eventual phytotoxicity and change in plant community (Gimmler et al., 2002). Heavy metals such as $\mathrm{Pb}, \mathrm{Cd}, \mathrm{Cu}$, and $\mathrm{Zn}$ have been reported to be released into the atmosphere during different operations of the road transport (Atayese et al., 2008; Sharma and Prasade, 2010; Zhang et al., 2012). Zhang et al., (2012) reported engine oil consumption as the largest emission for $\mathrm{Cd}$, tyres wear for $\mathrm{Zn}$, and brake wear for $\mathrm{Cu}$ and $\mathrm{Pb}$. Soil, vegetation and animals including man act as 'sinks' for atmospheric pollutants (Osibanjo and Ajayi, 1980). Heavy metals are that either 
leach into ground or surface water and enter into the growing food crops (Janos et al., 2010). From here, they migrate in to the food chain by direct or indirect usage of respective crops. Although some heavy metals like $\mathrm{Cu}$, $\mathrm{Fe}, \mathrm{Mn}, \mathrm{Zn}$ are required for growth of plants in trace amounts, but prove fatal if present beyond their maximum permissible limits (Freitas et al., 2010). Various heavy metals viz., arsenic, cadmium, copper, cobalt, lead, manganese, mercury, nickel and zinc are reported to cause genotoxicity upon reaching the living systems (Suciu et al., 2001; Chandra et al., 2005; Bertin et al., 2006). Organic matter and $\mathrm{pH}$ are the most important parameters controlling the accumulation and the availability of heavy metals in soil environment (Nyanangara and Mzezewa, 1999). It is necessary then to evaluate the relationship among these parameters and heavy metal accumulation in soil.

Heavy metal concentration in the soil solution plays an important role in controlling metal bioavailability to plants. The accumulation of heavy metals in crop plants is of great concern due to the probability of food contamination through the soil root interface. Though the heavy metal like, $\mathrm{Cd}$ and $\mathrm{Pb}$ are not essential for plant growth, they are readily taken up and accumulated by plants in toxic forms. Ingestion of vegetables irrigated with waste water and grown in soils contaminated with heavy metals possesses a possible risk to human health and wildlife. Presently, due to constraint in availability of fresh water for irrigation, waste water is being used for irrigation of agricultural fields resulting toxic metal contamination.

\section{Materials and Methods}

\section{Description of study area}

Jabalpur is situated at $23.90^{\circ} \mathrm{N}$ latitude and $79.58^{\circ}$ E longitude at an altitude of 411.78 meter above the mean sea level (MSL). Its present population is above 2 million (Fig. 1). Two decades back it was 7, 00,000. Rapid increase in population and change in life style have resulted in a dramatic increase in the generation of waste. Collection, transportation and handling of the waste must also be properly dealt with, if not, the waste creates a number of problems, many of which are related to human health and environment.

\section{Collection of wastewater, soil and plant samples}

Twenty water samples $(20+20=40)$ were collected along Omti Nala in rainy and winter seasons. GPS based $(80+80=160)$ soil and $(20+20=40)$ plant samples were collected at 200, 400, 600 and $800 \mathrm{~m}$ distances both sides of Omti Nala in rainy and winter seasons, respectively. These samples were analyzed for heavy metal concentration using AAS. Statistical analysis was carried out using SPSS 16.0 software. Maps were generated using Arc GIS 10.2 software. During the course of investigation various observations were taken viz,

Water samples that were used for irrigation practices were collected from each site in pre cleaned high-density polyethylene bottles. These bottles were rinsed earlier with a metalfree soap and then soaked in $10 \% \mathrm{HNO}_{3}$ overnight, and finally washed with deionised water. The heavy metals in water were determined by Atomic Absorption Spectrophotometer.

\section{Soil sampling, processing and their chemical analysis}

Non soil particles e.g. stones, wooden pieces, rocks, gravels, organic debris were removed from soil. Soil was oven dried and this dried soil was sieved through a $2 \mathrm{~mm}$ sieve and stored in the labelled polythene sampling 
bags. The $\mathrm{pH}$ was determined in 1: 2.5 soilwater suspensions using digital $\mathrm{pH}$ meter (Jackson, 1973). The electrical conductivity of the 1: 2.5 soil- water extract was measured using solu bridge (Jackson, 1973). The organic carbon was determined by rapid titration method as described by Walkley and Black (1934). The DTPA (pH 7.3) extractable $\mathrm{Cr}, \mathrm{Ni}, \mathrm{Cd}$, and $\mathrm{Pb}$ extracted by $0.005 \mathrm{M}$ DTPA, $0.01 \mathrm{M} \mathrm{CaCl}_{2}$ and $0.1 \mathrm{M}$ Triethanol amine (TEA) and analyzed on atomic absorption spectrometer (Norvell and Lindsay, 1978).

\section{Plant sampling, processing and their chemical analysis}

A diversity of crops and vegetables are grown in the study area; Rice, Wheat and vegetables were collected from each site of the sampling zone and stored in labelled polythene sampling bags.

\section{Chemical analysis of plant}

Weigh $1 \mathrm{~g}$ plant sample in a conical flask (corning, $100 \mathrm{ml}$ capacity). Add 10 to $12 \mathrm{ml}$ of di acid mixture (1 part perchloric +3 part nitric acid) and digested the mixture on hot plate till the residue was colourless samples were then taken off, cooled diluted with distilled water and filtered through Whatman No.1 filter paper. Made up the volume of digested to $50 \mathrm{ml}$, Read for heavy metals content on atomic absorption spectrophotometer (AAS).

Soil to plant metal transfer was computed as transfer factor (TF), which was calculated by using the equation

$\mathrm{TF}=\mathrm{C}_{\text {Plant }} / \mathrm{DTPA} \mathrm{C}_{\text {Soil }}$

Where, $\mathrm{C}_{\text {Plant }}$ is the concentration of heavy metals in plants and DTPA $\mathrm{C}_{\text {Soil }}$ is the Di ethylene thiamine penta acetic acid concentration of heavy metals in soil.
To investigate whether there are differences in the heavy metal concentrations between the two sites, discriminate analysis was used. The results of this analysis were assessed by examining the canonical correlation statistics, the Wilk's lambda, the significance level and the percentage of original group cases correctly classified. In order to quantitatively analyze and confirm the relationship among soil properties ( $\mathrm{pH}$ and $\mathrm{OC}$ ) and heavy metal content, a Pearson's correlation analysis was applied to dataset.

PCA was adopted to assist the interpretation of elemental data. This powerful method allows identifying the different groups of metals that correlate and thus can be considered as having a similar behavior and common origin. The theoretical aspects of these statistical methods have been described in advanced statistical literatures. It should be noted that parametric statistical tests require the data to be normally distributed. Therefore, it was checked if the data came from a population with normal distribution by applying Shapiro-Wilk's test (significance level, $=0.05)$. The non-normal data were transferred logarithmically to ensure normal distribution. All the statistical analysis were performed using SPSS for Windows (release Ver.11, Inc, Chicago, IL) and spatio-temporal maps of physio-chemical and heavy metals in soils were prepared using GIS open sources software.

\section{Results and Discussion}

\section{Concentration of heavy metals in water}

The irrigation water was neutral in reaction with $\mathrm{pH}$ values ranged from 6.50 to 8.50 with mean value of 7.77 and 7.52 to 8.81 with an average value of 8.16 in rainy and winter season, respectively. The electrical conductivity (EC) value of water ranged from 0.59 to $0.78 \mathrm{dSm}^{-1}$ with mean value of 0.69 
$\mathrm{dSm}^{-1}$ and 0.67 to $0.93 \mathrm{dSm}^{-1}$ with mean value of $0.77 \mathrm{dSm}^{-1}$ in rainy and winter season, respectively. The concentration of $\mathrm{Ni}$ in waste water ranged from 0.000 to 0.014 and 0.001 to 0.025 with an average value of 0.001 and $0.010 \mathrm{mgL}^{-1}$ in rainy and winter seasons, respectively. The concentration of $\mathrm{Cr}$ in waste water ranged from 0.015 to 4.171 and 0.004 to 0.058 with an average value of 0.787 and $0.028 \mathrm{mgL}^{-1}$ in rainy and winter seasons, respectively. The concentrations of $\mathrm{Cd}$ in waste water were negligible in rainy and winter seasons, respectively. However, the concentrations of $\mathrm{Pb}$ in waste water ranged from 0.00 to 0.26 and 0.001 to 0.050 with an average value of 0.100 and $0.009 \mathrm{mLL}^{-1}$ in rainy and winter seasons, respectively. The permissible limit suggested by $\mathrm{WHO}$ and Indian standard by Awasthi (2000) were 0.2 and $1.4 \mathrm{mgL}^{-1}, 0.1$ and 0.05 $\mathrm{mg} \mathrm{L}^{-1}, 0.05$ and $0.01 \mathrm{mg} \mathrm{L}^{-1}$ and 0.01 and $0.10 \mathrm{mgL}^{-1}$ for $\mathrm{Ni}, \mathrm{Cr}, \mathrm{Cd}$ and $\mathrm{Pb}$, respectively.

The $\mathrm{pH}$ ranged from 6.0 to 7.0 is normally considered to be the most desirable for irrigation water. However, our results indicating slightly alkaline water, this may be due to the presence of carbonate and bicarbonate. The EC provides a rapid and convenient means for estimating the concentration of electrolytes and gives information about all the dissolved minerals (Ahmed et al., 2002). BIS $<0.25 \mathrm{dSm}^{-1}$ in considered good and $>0.75 \mathrm{dSm}^{-1}$ is unsuitable for irrigation. The higher EC causes inhabits of the plant to compete with ion in soil solution for water, thus less is available to crop plants, usable plant water in soil solution decreases dramatically as EC increases. In water which is being used for irrigation in the cultivation of food crops particularly vegetables, the concentration of $\mathrm{Pb}$ and $\mathrm{Cr}$ was higher compared with the Indian permissible limits (Awashthi, 2000). Certain factors that may affect total contents of organic matter, season, average rainfall and stream discharge level. For example Qadir et al., 2008 reported that the highest concentrations for $\mathrm{EC}, \mathrm{Pb}$ and $\mathrm{Cd}$ were recorded during winter season which gradually reduced from spring season to monsoon. Whereas during the rainfall Nala will flow at high discharge level and dilute the total contents and lower concentrations are recorded. In the Jabalpur city, millions of litres wastewater is generated per day that drains into the Nala. Industrial and municipal sewage of city are discharged in these drainages, which is the main route of heavy metal accumulation in wastewater (Wozniak and Huang, 1982). Jayaprakash et al., (2010) indicated that the marshy region is more heavily contaminated with $\mathrm{Cd}, \mathrm{Hg}, \mathrm{Cr}, \mathrm{Cu}$, $\mathrm{Ni}, \mathrm{Pb}$, and $\mathrm{Zn}$ than other regions on the southeast coast of India. A study had also revealed the dominance of heavy metals present in Pallikaranai wetland following the sequence: $\quad \mathrm{Pb}>\mathrm{Cr}>\mathrm{Fe}>\mathrm{Ni}>\mathrm{Zn}>\mathrm{Cd}>\mathrm{Cu}$ (Ramachandran et al., 2012). In addition, the presence of heavy metals like lead, cadmium, zinc, cobalt, chromium etc. in the environment associated with industrial areas of Ranipet and Vellore are well accounted by many research papers (Mahesh and Selvaraj, 2008; Gowd and Govil, 2008; Saraswathy et al., 2010; Ambiga and Annadurai, 2013). Similarly results were also reported by Kar $e t$ al., 2008 and Rana et al., 2010)

\section{Status of metals in soil}

In rainy and winter seasons, the $\mathrm{pH}$ in soils ranged from 6.44 to 8.30 with mean value of 7.71 and 6.38 to 8.25 with mean value of 7.51 , respectively. The EC in soil ranged from 0.07 to 0.97 with mean value of 0.17 and 0.11 to $0.68 \mathrm{dSm}^{-1}$ with mean value of $0.27 \mathrm{dSm}^{-1}$ in rainy and winter seasons, respectively. The organic carbon content in soils ranged from 1.20 to $6.76 \mathrm{~g} \mathrm{~kg}^{-1}$ with mean value of 4.02 and 1.26 to $8.57 \mathrm{~g} \mathrm{~kg}^{-1}$ with mean value of 
$4.69 \mathrm{~g} \mathrm{~kg}^{-1}$ in rainy and winter seasons, respectively. Data revealed that the status of organic carbon content was low to medium soil samples collected from both side of Omti Nala of Jabalpur city.

The $\mathrm{Ni}$ concentration in soils ranged from 0.35 to $1.55 \mathrm{mgkg}^{-1}$ with an average value of 0.63 and 0.00 to $2.83 \mathrm{mgkg}^{-1}$ with an average value of $0.97 \mathrm{mgkg}^{-1}$ in rainy and winter seasons, respectively. The $\mathrm{Cr}$ concentration in soils varied from 0.00 to 0.88 with mean value of 0.39 and 0.00 to $2.01 \mathrm{mgkg}^{-1}$ with mean value of $0.16 \mathrm{mgkg}^{-1}$ in rainy and winter seasons, respectively. The values of $\mathrm{Cd}$ in soils varied from 0.01 to 0.65 and 0.00 to $1.13 \mathrm{mgkg}^{-1}$ with an average value of 0.13 and 0.30 in rainy and winter seasons, respectively. The $\mathrm{Pb}$ accumulation in soils ranged from 0.56 to $7.24 \mathrm{mgkg}^{-1}$ with mean value of 3.40 and 0.00 to $16.00 \mathrm{mgkg}^{-1}$ with mean value of $5.98 \mathrm{mgkg}^{-1}$ in rainy and winter seasons, respectively. The mean data showed that the observed value of $\mathrm{Ni}, \mathrm{Cr}, \mathrm{Cd}$ and $\mathrm{Pb}$ in soil in both seasons was below than the permissible limit set by WHO and Indian standard. ANOVA result showed that the physicochemical properties and heavy metals concentration in soil were significant differed in rainy and winter seasons.

Soils of study area are neutral to slightly alkaline in reaction. This may be due to the reaction of carbonates with other elements present in soil. These results are substantiate by Godoy-Faundez, et al., (2008). Criteria given by Muhr et al., (1965) low conductivity indicating that salinity is not at all a problem (Singh, 2012). The low to medium status of organic carbon content might be due to unbalanced fertilization, high summer temperature and good aeration in the soil, resulting in rapid decomposition of it. Swarup et al., (2000) and Sharma et al., (2004) who reported that the amount of SOC in soils of India is relatively low, ranging from 0.1 to
$1 \%$ and typically less than $0.5 \%$. In present study, the metals concentration was below the permissible limits of the EU standard (European Union, 2002) and Indian standards (Awashthi, 2000). Continuous removal of metals by food crops (vegetables and cereals) grown at the wastewater irrigated soil and heavy metals leaching into the deeper layers of soil may be a reason of low concentration of heavy metals than the permissible limits (Singh et al., 2010). Similarly results were also reported by Tiwari et al., (2011) and Nazir et al., (2015).

\section{Physic-chemical properties of soil from both sides of Omti Nala at 200,400,600 and $800 \mathrm{~m}$ distances in both seasons}

In rainy season the $\mathrm{pH}$ in soils ranged from 6.85 to $8.28,6.87$ to $8.30,6.44$ to 8.15 and 6.88 to 8.24 with mean values of $7.78,7.71$, 7.63 and 7.68 at 200,400,600 and $800 \mathrm{~m}$ distances, respectively. However, 6.38 to $8.21,6.75$ to $8.25,6.65$ to 8.25 and 6.67 to 8.22 with mean value of $7.52,7.52,7.48$ and 7.53 at 200,400,600 and $800 \mathrm{~m}$, respectively in winter season. In rainy season the EC in soil ranged from 0.08 to $0.35,0.08$ to 0.97 , 0.08 to 0.35 and 0.07 to $0.86 \mathrm{dSm}^{-1}$ with mean values of $0.15,0.20,0.14$ and $0.19 \mathrm{dSm}^{-1}$ at $200,400,600$ and $800 \mathrm{~m}$, respectively. However, 011 to $0.68,0.15$ to $0.47,0.13$ to 0.53 and 0.11 to $0.61 \mathrm{dSm}^{-1}$ with mean values of $027,0.24,0.28$ and $0.26 \mathrm{dSm}^{-1}$ at 200 , 400,600 and $800 \mathrm{~m}$, respectively in winter season. In rainy season the $\mathrm{OC}$ in soil ranged from 1.61 to $6.45,2.08$ to $5.79,1.31$ to 5.93 and 1.20 to $6.76 \mathrm{gkg}^{-1}$ with mean values of $4.04,4.11,3.77$ and $4.15 \mathrm{gkg}^{-1}$ at $200,400,600$ and $800 \mathrm{~m}$, respectively. However, 1.68 to $8.57,1.26$ to $7.81,1.46$ to 8.57 and 1.95 to $7.60 \mathrm{~g} \mathrm{~kg}^{-1}$ with mean value of $4.81,4.64$, 5.00 and $4.33 \mathrm{gkg}^{-1}$ at 200, 400, 600 and 800 $\mathrm{m}$, respectively, in winter season. ANOVA result were also indicated that the $\mathrm{pH}, \mathrm{EC}$ and OC content in soil were not significant 
differed with the increasing distance from the Omti nala in rainy and winter seasons.

\section{Heavy metals accumulation in soils}

The $\mathrm{Ni}$ in soils ranged from 0.40 to $1.55,0.45$ to $1.02,0.42$ to 0.85 and 035 to 1.34 with mean values of $0.66,0.63,0.60$ and 0.64 at 200, 400, 600 and $800 \mathrm{~m}$, respectively in rainy season. However, 0.00 to $1.77,0.00$ to $2.02,0.00$ to 2.83 and 0.00 to 1.78 with mean value of $0.99,0.99,1.03$ and 0.95 at $200,400,600$ and $800 \mathrm{~m}$, respectively in winter season. The $\mathrm{Cr}$ in soils ranged from 0.03 to $0.67,0.00$ to $0.74,0.10$ to 0.88 and 0.17 to 0.82 with mean values of $0.37,0.39$, 0.38 and 0.41 at 200, 400, 600 and $800 \mathrm{~m}$, respectively in rainy season. However, 0.00 to $0.37,0.00$ to $054,0.00$ to 2.01 and 0.00 to 0.31 with mean value of $0.14,0.16,0.22$ and 0.12 at 200, 400, 600 and $800 \mathrm{~m}$, respectively in winter season. The $\mathrm{Cd}$ in soils ranged from 0.03 to $0.41,0.05$ to $0.65,0.04$ to 0.36 and 0.01 to 0.47 with mean values of $0.13,0.13$, 0.12 and 0.13 at $200,400,600$ and $800 \mathrm{~m}$, respectively in rainy season. However, 0.00 to $1.13,0.00$ to $0.72,0.00$ to 0.81 and 0.00 to 0.71 with mean value of $0.34,0.26,0.35$ and 0.25 at 200, 400, 600 and $800 \mathrm{~m}$, respectively in winter season. In winter season the $\mathrm{Pb}$ in soils ranged from 1.68 to $7.24,1.22$ to 5.82 , 1.44 to 6.76 and 0.56 to 6.18 with mean values of $3.53,3.33,3.39$ and 3.34 at $200,400,600$ and $800 \mathrm{~m}$, respectively in rainy season. However, 0.00 to $15.00,0.00$ to $15.00,0.00$ to 16.00 and 0.00 to 13.00 with mean value of $6.20,5.75,6.81$ and 5.17 at 200, 400, 600 and $800 \mathrm{~m}$, respectively. ANOVA result showed that the metals concentrations in soil were not significant differed from the different distance from Omti nala in rainy and winter seasons.

Data indicated that these soils are neutral to alkaline in reaction, whereas EC of soil were categorized as normal. It may also be due to formation of these soils from basaltic parent material rich in basic cations. Similar findings were reported by Jibhakate et al., (2009). Mandal et al., (2007) observed that crop species and cropping systems that may also play an important role in maintaining SOC stock because both quantity and quality of their residues that are returned to the soils vary greatly affecting their turnover or residence time in soil and thus its quality. Soil type and plant community significantly affected the SOC (Yang et al., 2014).Lower content of heavy metals in black soils is due to its fixation by clay due to high soil $\mathrm{pH}$ values which have resulted in the formation of insoluble compounds (Tandon 1995). Similarly results were also reported by Ekmekyapar et al., (2012).

\section{Concentration of heavy metal in crops/vegetables}

On dry weight basis the concentration of $\mathrm{Ni}$, $\mathrm{Cr}, \mathrm{Cd}$ and $\mathrm{Pb}$ in rice, ranged from 2.70 $\mathrm{mgkg}^{-1}$ (S-8) to $10.35 \mathrm{mgkg}^{-1}$ (S-37); 7.00 $\mathrm{mgkg}^{-1}$ (S-67) to $18.70 \mathrm{mgkg}^{-1}$ (S-45); 0.20 $\mathrm{mgkg}^{-1}$ (S-67) to $0.80 \mathrm{mgkg}^{-1}$ (S-36) and 1.45 $\mathrm{mgkg}^{-1}(\mathrm{~S}-15)$ to $15.50 \mathrm{mgkg}^{-1}$ (S-63) in rainy season. In winter season, the concentration of $\mathrm{Ni}, \mathrm{Cr}, \mathrm{Cd}$ and $\mathrm{Pb}$ in wheat (Triticum aestivum), ranged from $2.70 \mathrm{mgkg}^{-1}(\mathrm{~S}-8)$ to $10.35 \mathrm{mgkg}^{-1} 1(\mathrm{~S}-37) ; 7.00 \mathrm{mgkg}^{-1}(\mathrm{~S}-67)$ to $18.70 \mathrm{mgkg}^{-1}(\mathrm{~S}-45) ; 0.20 \mathrm{mgkg}^{-1}$ (S-67) to $0.80 \mathrm{mgkg}^{-1}(\mathrm{~S}-36)$ and $1.45 \mathrm{mgkg}^{-1}(\mathrm{~S}-15)$ to $15.50 \mathrm{mgkg}^{-1}(\mathrm{~S}-63)$. The concentration of $\mathrm{Ni}$, $\mathrm{Cr}, \mathrm{Cd}$ and $\mathrm{Pb}$ in Spinach (Spinacea oleracea), 6.80 and 6.70, 9.15 and 13.50, 1.30 and 0.55 and 17.50 and $19.50 \mathrm{mgkg}^{-1}$ in $\mathrm{S}-9$ and S-80 sites, respectively in winter season. The concentration of $\mathrm{Ni}, \mathrm{Cr}, \mathrm{Cd}$ and $\mathrm{Pb}$ in sugar beet (Beta vulgaris), 7.15, 9.65, 0.80 and $11 \mathrm{mgkg}^{-1}$ in $\mathrm{S}-42$ site, respectively in winter season. The concentration of $\mathrm{Ni}, \mathrm{Cr}$, $\mathrm{Cd}$ and $\mathrm{Pb}$ in Tomato (Lycopresicon esculantum), 4.53 and 7.70, 10.40 and 13.30, 0.75 and 0.85 and 0.95 and $12.50 \mathrm{mgkg}^{-1}$ in $\mathrm{S}$ - 
8 and S-40 sites, respectively in winter season. The observed values of $\mathrm{Ni} \mathrm{Cr}$ and $\mathrm{Cd}$ were safe as permissible limit given by WHO/Indian standard. However, the concentration of $\mathrm{Pb}$ was higher than the limit given by WHO/Indian standard. The concentration of $\mathrm{Ni}, \mathrm{Cr}, \mathrm{Cd}$ and $\mathrm{Pb}$ in Brinjal (Solanum melongena), were 8.15, 11.85 and 15.90, 16.10, 19.10 and 29.10, 1.60, 1.80 and 2.10 and $16.50,22.00$ and $32.00 \mathrm{mgkg}^{-1}$ at S$11, \mathrm{~S}-17$ and $\mathrm{S}-13$, respectively in winter season. The observed value of $\mathrm{Ni}$ was safe as permissible limit given by $\mathrm{WHO} /$ Indian standard. However, the concentration of $\mathrm{Cr}$, $\mathrm{Cd}$ and $\mathrm{Pb}$ were higher than the limit given by WHO/Indian standard. In the present study, metals concentrations in the all vegetables were in the range of Indian safe limits (Awashthi, 2000) except $\mathrm{Pb}$ which was greater. However, concentration of $\mathrm{Cr}$ and $\mathrm{Cd}$ were also exceeding the safe limits in Brinjal. $A$ variation in the metal concentration may be due to the variable factors like heavy metal concentration in soil; wastewater used for irrigation, atmospheric deposition and plant's capability to uptake and accumulates the heavy metals (Pandey et al., 2012). Wastewater used for the irrigation purposes may route the uptake of heavy metals from roots to the edible parts of the vegetables. It was found that the leafy vegetables have a higher concentration of heavy metals. Further, in vicinity to the study area a number of industries and automobiles emit their smoke in the open air; the atmosphere of that area remains smoky and this smoke contains various toxic metals that may cause atmospheric deposition of heavy metals on the leaves of vegetables, which may be a reason of higher concentration of heavy metals in leafy vegetables (Khan et al., 2010). Jan et al., (2010) and Akbar et al., (2009) also indicated that the vegetables grown in wastewater accumulate higher concentration of heavy metals than those vegetables grown at the ground water. Metal concentration and uptake differed among the studied soils among different plant species and may be attributed, to the soil properties, such as organic carbon, soil $\mathrm{pH}$, clay and free $\mathrm{Fe}$ contents. It is well documented that free $\mathrm{Fe}$ oxides are the dominant soil constituents responsible for metal sorption (Fendorf et al., 1997), and soil organic matter can also adsorb metals, thus reducing its availability (Redman et al., 2002). Our results corroborate the findings of McLaren et al., (2006) that have indicated acidic soil $\mathrm{pH}$ and low clay content caused low sorption on inorganic pollutants. Similarly results were also reported by Karatas et al., (2006) and Chauhan (2014).

\section{Transfer factor of metals from soil to crops and vegetables}

The metal transfer factor for Brinjal (Solanum melongena) was 68.90, 75.46 and 93.92, 14.25, 20.99 and 27.45, 3.02, 3.60 and 1.29, 1.82 and 4.58 , for $\mathrm{Ni}, \mathrm{Cr}, \mathrm{Cd}$ and $\mathrm{Pb}$, respectively. $\mathrm{Ni} \mathrm{TF}$ was the highest for Brinjal (Solanum melongena) (93.92), followed by the Spinach (Spinacea oleracea) (40.96) and Tomato (Lycopresicon esculantum) (35.08). Cr TF was the highest for Brinjal (Solanum melongena) (27.45), followed by the Spinach (Spinacea oleracea) (8.79) and Tomato (Lycopresicon esculantum) (14.05). Cd TF was the highest for Brinjal (Solanum melongena) (7.39), followed by the Spinach (Spinacea oleracea) (4.66) and Tomato (Lycopresicon esculantum) (1.89). Pb $\mathrm{TF}$ was the highest for Brinjal (Solanum melongena) (4.58), followed by the Spinach (Spinacea oleracea) (7.74) and Tomato (Lycopresicon esculantum) (0.07). Cr TF was the highest for rice compared to wheat.

Metal transfer factor from soil to plants is a key module of human exposure to heavy metals via food chain. Transfer factor of metals is essential to investigate the human health risk index (Cui et al., 2004). TF of 
metals varied significantly in different vegetables. Among vegetables, Brinjal (Solanum melongena), Tomato (Lycopresicon esculantum) and Spinach (Spinacea oleracea) showed a higher metal transfer factor from soil to plants than other vegetables. Leafy vegetable has a higher transpiration rate to sustain the growth and moisture content of plant that may be the reason of high uptake of metals in them (Tani and Barrington, 2005; Lato et al., 2012). Similar results were also reported by Jan et al., (2010) and Khan et al., (2010). Similarly results were also reported by Mahmood and Malik (2013).

\section{Relationship of metals with physic- chemical properties of soil}

In rainy season, the $\mathrm{pH}$ was negatively correlated with $\mathrm{OC}\left(\mathrm{r}=-0.252^{*}\right)$ and $\mathrm{Cr}(\mathrm{r}=-$ $\left.0.413^{* *}\right)$. In winter season, $\mathrm{pH}$ showed significant negative relation with $\mathrm{EC}(\mathrm{r}=$ $\left.0.601^{* *}\right)$, OC $\left(\mathrm{r}=-0.356^{* *}\right), \mathrm{Cd}\left(\mathrm{r}=-0.696^{* *}\right)$ and $\mathrm{Pb}\left(\mathrm{r}=-0.619^{* *}\right)$. While, it had significant positive relationship with $\mathrm{Cr}(\mathrm{r}=0.304 * *)$. In winter season, the EC had positive and significant relationship with OC $\left(\mathrm{r}=0.239^{*}\right)$, $\mathrm{Cd}\left(\mathrm{r}=0.366^{* *}\right)$ and $\mathrm{Pb}\left(\mathrm{r}=0.420^{* *}\right)$. The $\mathrm{OC}$ showed significant positive relationship with $\mathrm{Ni} \quad\left(\mathrm{r}=0.305^{* *}\right), \quad \mathrm{Cd} \quad\left(\mathrm{r}=0.279^{*}\right)$ and $\mathrm{Pb}$ $\left(\mathrm{r}=0.232^{*}\right)$ in rainy season whereas it had showed only $\mathrm{Cd} \quad\left(\mathrm{r}=0.333^{* *}\right)$ and $\mathrm{Pb}$ $\left(\mathrm{r}=0.240^{*}\right)$ in winter season. Result showed the $\mathrm{Cr}$ in soil showed significant negative relationship with $\mathrm{Pb}\left(\mathrm{r}=-0.241^{*}\right)$ in rainy and positive with $\mathrm{Ni}\left(\mathrm{r}=0.438^{* *}\right)$ in winter season. The $\mathrm{Ni}, \mathrm{Cd}$ and $\mathrm{Pb}$ were positively related with each other in both rainy and winter season. Several earlier studies have reported that soil $\mathrm{pH}$ has a negative correlation with micronutrients for some calcareous alkaline soils (Chahal et al., 2005; Sharma et al., 2005; Murthy and Murthy 2005; Verma et al., 2013).

Data exhibited a significant positive correlation between $\mathrm{Cr}, \mathrm{Cd}$ and $\mathrm{Pb}$ in soil but $\mathrm{Ni}$ had no significant correlation in soil as well as plant. The data exhibited a significant positive correlation between $\mathrm{Cr}, \mathrm{Cd}$ and $\mathrm{Pb}$ in soil but $\mathrm{Ni}$ was not significant correlation in soil as well as plant. $\mathrm{Cd}$ and $\mathrm{Pb}$ in soil showed significant correlation with $\mathrm{Cr}$ having $\mathrm{r}=0.46^{*}$ and $0.38^{*}$, respectively. The $\mathrm{Cd}$ in soil showed significant and positively related with $\mathrm{Pb}$ in soil, $\mathrm{Ni}$ and $\mathrm{Cd}$ content in plant showing the $\mathrm{r}$ values of $\mathrm{r}=0.974^{* *}, 0.474^{*}$ and $0.699^{* *}$,respectively. The $\mathrm{Pb}$ content in soil had significant relationship with $\mathrm{Ni}$ and $\mathrm{Cd}$ content in plant. The $\mathrm{Ni}, \mathrm{Cr} \mathrm{Cd}$ and $\mathrm{Pb}$ content in plant were positively related with each other. Similar results were also reported by Bhattacharyya et al., (2005) (Table 1-8).

Table.1 Permissible limit for water, soil and plants

\begin{tabular}{|c|c|c|c|c|c|c|c|c|}
\hline \multirow[t]{2}{*}{ Parameters } & \multicolumn{3}{|c|}{ Indian standard } & $\mathbf{E U}$ & \multicolumn{3}{|c|}{ WHO } & \multirow{2}{*}{$\begin{array}{c}\text { FAO of } \\
\text { permissible limit } \\
\text { for irrigation } \\
\text { water }\end{array}$} \\
\hline & Water & Soil & Plant & Plant & Water & Soil & Plant & \\
\hline $\mathrm{Ni}$ (ppm) & 60 & 1.4 & 67 & 50 & 0.02 & $0.150-1.03$ & 10.00 & 0.20 \\
\hline $\mathrm{Cr}(\mathbf{p p m})$ & NA & 0.05 & 20 & 100 & 1.31 & 4.5 & 1.30 & 0.01 \\
\hline Cd(ppm) & $3-6$ & 0.01 & 1.5 & 3 & 0.004 & 0.30 & 0.02 & 2.0 \\
\hline $\mathrm{Pb}(\mathbf{p p m})$ & $250-500$ & 0.1 & 2.5 & 100 & 0.05 & 0.4 & 2.00 & 5.0 \\
\hline
\end{tabular}


Table. $2 \mathrm{pH}, \mathrm{EC}$ and heavy metals concentration in wastewater in rainy and winter seasons $(\mathrm{n}=20)$

\begin{tabular}{|c|c|c|c|c|c|c|c|c|c|c|c|c|c|c|}
\hline \multirow[t]{2}{*}{ ID } & \multirow[t]{2}{*}{ Lat } & \multirow[t]{2}{*}{ Long } & \multicolumn{2}{|c|}{ pH } & \multicolumn{2}{|c|}{$\operatorname{EC}\left(\mathrm{dSm}^{-1}\right)$} & \multicolumn{2}{|c|}{$\mathrm{Ni}\left(\mathrm{mgL}^{-1}\right)$} & \multicolumn{2}{|c|}{$\operatorname{Cr}\left(\mathrm{mgL}^{-1}\right)$} & \multicolumn{2}{|c|}{$\mathrm{Cd}\left(\mathrm{mgL}^{-1}\right)$} & \multicolumn{2}{|c|}{$\mathrm{Pb}\left(\mathrm{mgL}^{-1}\right)$} \\
\hline & & & Rainy & Winter & Rainy & Winter & Rainy & Winter & Rainy & Winter & Rainy & Winter & Rainy & Winter \\
\hline W-1 & $23^{\circ} 10^{\prime} 10.2^{\prime \prime}$ & $79^{\circ} 54^{\prime} 33.6^{\prime \prime}$ & 6.66 & 7.68 & 0.59 & 0.67 & ND & 0.003 & 0.703 & 0.006 & ND & 0.011 & ND & 0.004 \\
\hline W-2 & $23^{\circ} 10^{\prime} 06.7^{\prime \prime}$ & $79^{\circ} 54^{\prime} 32.1^{\prime \prime}$ & 7.19 & 8.34 & 0.66 & 0.68 & ND & 0.004 & 3.694 & 0.011 & ND & 0.011 & ND & 0.007 \\
\hline W-3 & $23^{\circ} 10^{\prime} 15.4^{\prime \prime}$ & $79^{\circ} 54^{\prime} 35.1^{\prime \prime}$ & 7.81 & 8.78 & 0.66 & 0.68 & ND & 0.001 & 4.171 & 0.008 & ND & 0.009 & ND & 0.004 \\
\hline W-4 & $23^{\circ} 10^{\prime} 22.9^{\prime \prime}$ & $79^{\circ} 54^{\prime} 30.1^{\prime \prime}$ & 6.50 & 8.21 & 0.69 & 0.71 & ND & 0.004 & 0.089 & 0.004 & ND & 0.010 & 0.260 & 0.005 \\
\hline W-5 & $23^{\circ} 10^{\prime} 28.8^{\prime \prime}$ & $79^{\circ} 54^{\prime} 16.1^{\prime \prime}$ & 7.20 & 8.81 & 0.78 & 0.70 & ND & 0.007 & 3.992 & 0.009 & ND & 0.004 & 0.050 & 0.002 \\
\hline W-6 & $23^{\circ} 11^{\prime} 57.5^{\prime \prime}$ & $79^{\circ} 53^{\prime} 22.6^{\prime \prime}$ & 6.91 & 8.05 & 0.67 & 0.69 & ND & 0.001 & 1.629 & 0.011 & ND & 0.004 & 0.020 & 0.002 \\
\hline W-7 & $23^{\circ} 11^{\prime} 53.5^{\prime \prime}$ & $79^{\circ} 53^{\prime} 25.2^{\prime \prime}$ & 7.45 & 7.76 & 0.65 & 0.69 & ND & 0.007 & 0.129 & 0.015 & ND & 0.004 & 0.030 & 0.001 \\
\hline W-8 & $23^{\circ} 11^{\prime} 50.6^{\prime \prime}$ & $79^{\circ} 53^{\prime} 25.4^{\prime \prime}$ & 8.20 & 8.73 & 0.64 & 0.75 & ND & 0.010 & 0.159 & 0.012 & ND & 0.006 & 0.170 & 0.013 \\
\hline W-9 & $23^{\circ} 11^{\prime} 46.5^{\prime \prime}$ & $79^{\circ} 53^{\prime 2} 26.4^{\prime \prime}$ & 7.80 & 8.12 & 0.65 & 0.75 & ND & 0.002 & 0.029 & 0.052 & ND & 0.006 & 0.060 & 0.005 \\
\hline W-10 & $23^{\circ} 11^{\prime} 55.2^{\prime \prime}$ & $79^{\circ} 53^{\prime} 20.3 ”$ & 8.23 & 8.56 & 0.65 & 0.75 & ND & 0.010 & 0.075 & 0.023 & ND & 0.005 & 0.080 & 0.003 \\
\hline W-11 & $23^{\circ} 11^{\prime} 57.4^{\prime \prime}$ & $79^{\circ} 53^{\prime} 21.6^{\prime \prime}$ & 8.35 & 8.00 & 0.65 & 0.77 & ND & 0.006 & 0.015 & 0.028 & ND & 0.005 & 0.090 & 0.001 \\
\hline W-12 & $23^{\circ} 12^{\prime} 03.4^{\prime \prime}$ & $79^{\circ} 53^{\prime} 22.6^{\prime \prime}$ & 8.30 & 8.16 & 0.65 & 0.87 & ND & 0.013 & 0.016 & 0.033 & ND & 0.006 & 0.060 & 0.005 \\
\hline W-13 & $23^{\circ} 12^{\prime} 43.4^{\prime \prime}$ & $79^{\circ} 53^{\prime} 06.8^{\prime \prime}$ & 8.10 & 8.52 & 0.75 & 0.83 & ND & 0.022 & 0.072 & 0.058 & ND & 0.007 & 0.100 & 0.003 \\
\hline W-14 & $23^{\circ} 12^{\prime} 46^{\prime \prime}$ & $79^{\circ} 53^{\prime} 00.4^{\prime \prime}$ & 8.34 & 7.96 & 0.73 & 0.93 & ND & 0.019 & 0.088 & 0.029 & ND & 0.011 & 0.150 & 0.002 \\
\hline W-15 & $23^{\circ} 13^{\prime} 34.1^{\prime \prime}$ & 7953’3.9”' & 8.05 & 7.70 & 0.73 & 0.88 & ND & 0.004 & 0.042 & 0.050 & ND & 0.005 & 0.230 & 0.001 \\
\hline W-16 & $23^{\circ} 14^{\prime} 25.1^{\prime \prime}$ & $79^{\circ} 53^{\prime} 38.9^{\prime \prime}$ & 7.91 & 7.90 & 0.73 & 0.80 & 0.001 & 0.022 & 0.334 & 0.054 & ND & 0.008 & 0.170 & 0.004 \\
\hline W-17 & $23^{\circ} 14^{\prime} 44.1^{\prime \prime}$ & $79^{\circ} 53^{\prime} 58.8^{\prime \prime}$ & 8.32 & 8.12 & 0.72 & 0.84 & 0.007 & 0.024 & 0.189 & 0.045 & ND & 0.009 & 0.120 & 0.005 \\
\hline W-18 & $23^{\circ} 14^{\prime} 49.4^{\prime \prime}$ & $79^{\circ} 53^{\prime} 57.6^{\prime \prime}$ & 8.40 & 7.52 & 0.73 & 0.89 & ND & 0.006 & 0.041 & 0.056 & ND & 0.001 & 0.220 & 0.007 \\
\hline W-19 & $23^{\circ} 14^{\prime} 57^{\prime \prime}$ & $79^{\circ} 54^{\prime} 0.4^{\prime \prime}$ & 7.73 & 8.35 & 0.68 & 0.69 & ND & 0.009 & 0.025 & 0.041 & ND & ND & 0.180 & 0.050 \\
\hline W-20 & $23^{\circ} 15^{\prime} 2.4^{\prime \prime}$ & $79^{\circ} 53^{\prime} 54.6^{\prime \prime}$ & 7.90 & 7.92 & 0.69 & 0.88 & 0.014 & 0.025 & 0.244 & 0.018 & ND & 0.005 & 0.010 & 0.050 \\
\hline \multicolumn{3}{|c|}{ Min } & 6.50 & 7.52 & 0.59 & 0.67 & ND & 0.001 & 0.015 & 0.004 & ND & ND & ND & 0.001 \\
\hline \multicolumn{3}{|c|}{ Max } & 8.40 & 8.81 & 0.78 & 0.93 & 0.014 & 0.025 & 4.171 & 0.058 & ND & 0.011 & 0.260 & 0.050 \\
\hline \multicolumn{3}{|c|}{ Mean } & 7.77 & 8.16 & 0.69 & 0.77 & 0.001 & 0.010 & 0.787 & 0.028 & ND & 0.006 & 0.100 & 0.009 \\
\hline \multicolumn{3}{|c|}{$\begin{array}{c}\text { WHO/Indian standard Awasthi } \\
\text { (2000) }\end{array}$} & & & & & \multicolumn{2}{|c|}{$0.2 / 1.4$} & \multicolumn{2}{|c|}{$0.1 / 0.05$} & \multicolumn{2}{|c|}{$0.05 / 0.01$} & \multicolumn{2}{|c|}{$0.01 / 0.1$} \\
\hline
\end{tabular}


Table.3 Descriptive statistics of soil properties $(n=80+80=160)$

\begin{tabular}{|c|c|c|c|c|c|c|c|c|c|c|c|c|c|c|}
\hline \multirow[t]{2}{*}{$\begin{array}{l}\text { Para } \\
\text { meter }\end{array}$} & \multicolumn{2}{|c|}{ Min } & \multicolumn{2}{|c|}{ Max } & \multicolumn{2}{|c|}{ Mean } & \multicolumn{2}{|c|}{ S.E } & \multicolumn{2}{|c|}{ SD } & \multicolumn{2}{|c|}{$\begin{array}{l}\text { ANOVA result } \\
\text { for seasons }\end{array}$} & \multirow[t]{2}{*}{$\begin{array}{c}\mathbf{E U} \\
(\mathbf{2 0 0 6})\end{array}$} & \multirow[t]{2}{*}{$\begin{array}{c}\text { Indian } \\
\text { Standard }\end{array}$} \\
\hline & $\mathbf{R}$ & W & $\mathbf{R}$ & W & $\mathbf{R}$ & W & $\mathbf{R}$ & W & $\mathbf{R}$ & W & F value & Sig. & & \\
\hline pH & 6.44 & 6.38 & 8.30 & 8.25 & 7.71 & 7.51 & 0.04 & 0.06 & 0.40 & 0.50 & 7.31 & $* *$ & & \\
\hline EC & 0.07 & 0.11 & 0.97 & 0.68 & 0.17 & 0.27 & 0.02 & 0.01 & 0.14 & 0.13 & 19.48 & $* *$ & & \\
\hline OC & 1.20 & 1.26 & 6.76 & 8.57 & 4.02 & 4.69 & 0.15 & 0.22 & 1.33 & 1.98 & 6.43 & * & & \\
\hline $\mathrm{Ni}$ & 0.35 & 0.00 & 1.55 & 2.83 & 0.63 & 0.97 & 0.02 & 0.07 & 0.19 & 0.60 & 23.92 & ** & 50.00 & $75-150$ \\
\hline $\mathrm{Cr}$ & 0.00 & 0.00 & 0.88 & 2.01 & 0.39 & 0.16 & 0.02 & 0.03 & 0.21 & 0.24 & 42.21 & ** & 100.00 & NA \\
\hline Cd & 0.01 & 0.00 & 0.65 & 1.13 & 0.13 & 0.30 & 0.01 & 0.03 & 0.10 & 0.25 & 32.57 & ** & 3.00 & 03-06 \\
\hline $\mathbf{P b}$ & 0.56 & 0.00 & 7.24 & 16.00 & 3.40 & 5.98 & 0.15 & 0.49 & 1.32 & 4.41 & 25.26 & $* *$ & 100.00 & $250-500$ \\
\hline
\end{tabular}

Table.4 Physic-chemical properties of soil from both sides of Omti Nala at 200,400,600 and 800 $\mathrm{m}$ distances in both season $(\mathrm{n}=80$ in each season)

\begin{tabular}{|c|c|c|c|c|c|c|c|}
\hline \multirow[t]{2}{*}{ Variables } & \multirow[t]{2}{*}{ Season } & \multicolumn{4}{|c|}{ Distance (m) } & \multicolumn{2}{|c|}{ ANOVA result for distances } \\
\hline & & 200 & 400 & 600 & 800 & F value & Sign \\
\hline \multirow[t]{2}{*}{ pH } & Rainy & $\begin{array}{c}6.85-8.28 \\
(7.78)\end{array}$ & $\begin{array}{c}6.87-8.3 \\
(7.71)\end{array}$ & $\begin{array}{c}6.44-8.15 \\
(7.63)\end{array}$ & $\begin{array}{c}6.88-8.24 \\
(7.68)\end{array}$ & 0.483 & NS \\
\hline & Winter & $\begin{array}{c}6.38-8.21 \\
(7.52)\end{array}$ & $\begin{array}{c}6.75-8.25 \\
(7.52)\end{array}$ & $\begin{array}{c}6.65-8.25 \\
(7.48)\end{array}$ & $\begin{array}{c}6.67-8.22 \\
(7.53)\end{array}$ & 0.047 & NS \\
\hline \multirow[t]{2}{*}{$\begin{array}{c}\mathrm{EC} \\
\left(\mathrm{dSm}^{-1}\right)\end{array}$} & Rainy & $\begin{array}{c}0.08-0.35 \\
(0.15)\end{array}$ & $\begin{array}{c}0.08-0.97 \\
(0.20)\end{array}$ & $\begin{array}{c}0.08-0.35 \\
(0.14)\end{array}$ & $\begin{array}{c}0.07-0.86 \\
(0.19)\end{array}$ & 0.773 & NS \\
\hline & Winter & $\begin{array}{c}0.11-0.68 \\
(0.27)\end{array}$ & $\begin{array}{c}0.15-0.47 \\
(0.24)\end{array}$ & $\begin{array}{c}0.13-0.53 \\
(0.28)\end{array}$ & $\begin{array}{c}0.11-0.61 \\
(0.26)\end{array}$ & 0.367 & NS \\
\hline \multirow[t]{2}{*}{$\underset{\left(\mathrm{gkg}^{-1}\right)}{\mathrm{OC}}$} & Rainy & $\begin{array}{c}1.61-6.45 \\
(4.04)\end{array}$ & $\begin{array}{c}2.08-5.79 \\
(4.11)\end{array}$ & $\begin{array}{c}1.31-5.93 \\
(3.77)\end{array}$ & $\begin{array}{c}1.20-6.76 \\
(4.15)\end{array}$ & 0.342 & NS \\
\hline & Winter & $\begin{array}{c}1.68-8.57 \\
(4.81)\end{array}$ & $\begin{array}{c}1.26-7.81 \\
(4.64)\end{array}$ & $\begin{array}{c}1.46-8.57 \\
(5.00)\end{array}$ & $\begin{array}{c}1.95-7.60 \\
(4.33)\end{array}$ & 0.396 & NS \\
\hline \multirow[t]{2}{*}{$\begin{array}{c}\mathbf{N i} \\
\left(\mathbf{m g k g}^{-1}\right)\end{array}$} & Rainy & $\begin{array}{c}0.40-1.55 \\
(0.66)\end{array}$ & $\begin{array}{c}0.45-1.02 \\
(0.63)\end{array}$ & $\begin{array}{c}0.42-0.85 \\
(0.60)\end{array}$ & $\begin{array}{c}0.35-1.34 \\
(0.64)\end{array}$ & 0.399 & NS \\
\hline & winter & $\begin{array}{c}0.00-1.77 \\
(0.99)\end{array}$ & $\begin{array}{c}0.00-2.02 \\
(0.92)\end{array}$ & $\begin{array}{c}0.00-2.83 \\
(1.03)\end{array}$ & $\begin{array}{c}0.00-1.78 \\
(0.95)\end{array}$ & 0.131 & NS \\
\hline \multirow[t]{2}{*}{$\begin{array}{c}\mathbf{C r} \\
\left(\mathbf{m g k g}^{-1}\right)\end{array}$} & Rainy & $\begin{array}{c}0.03-0.67 \\
(0.37)\end{array}$ & $\begin{array}{c}0.00-0.74 \\
(0.39)\end{array}$ & $\begin{array}{c}0.10-0.88 \\
(0.38)\end{array}$ & $\begin{array}{c}0.17-0.82 \\
(0.41)\end{array}$ & 0.106 & NS \\
\hline & winter & $\begin{array}{c}0.00-0.37 \\
(0.14)\end{array}$ & $\begin{array}{c}0.00-0.54 \\
(0.16)\end{array}$ & $\begin{array}{c}0.00-2.01 \\
(0.22)\end{array}$ & $\begin{array}{c}0.00-0.31 \\
(0.12)\end{array}$ & 0.701 & NS \\
\hline \multirow[t]{2}{*}{$\begin{array}{c}\mathbf{C d} \\
\left(\mathbf{m g k g}^{-1}\right)\end{array}$} & Rainy & $\begin{array}{c}0.03-0.41 \\
(0.13)\end{array}$ & $\begin{array}{c}0.05-0.65 \\
(0.13)\end{array}$ & $\begin{array}{c}0.04-0.36 \\
(0.12)\end{array}$ & $\begin{array}{c}0.01-0.47 \\
(0.13)\end{array}$ & 0.092 & NS \\
\hline & winter & $\begin{array}{c}0.00-1.13 \\
(0.34)\end{array}$ & $\begin{array}{c}0.00-0.72 \\
(0.26)\end{array}$ & $\begin{array}{c}0.00-0.81 \\
(0.35)\end{array}$ & $\begin{array}{c}0.00-0.71 \\
(0.25)\end{array}$ & 0.773 & NS \\
\hline \multirow[t]{2}{*}{$\begin{array}{c}\mathbf{P b} \\
\left(\mathbf{m g k g}^{-1}\right)\end{array}$} & Rainy & $\begin{array}{c}1.68-7.24 \\
(3.53)\end{array}$ & $\begin{array}{c}1.22-5.82 \\
(3.33)\end{array}$ & $\begin{array}{c}1.44-6.76 \\
(3.39)\end{array}$ & $\begin{array}{c}0.56-6.18 \\
(3.34)\end{array}$ & 0.094 & NS \\
\hline & winter & $\begin{array}{c}0.00-15.00 \\
(6.20)\end{array}$ & $\begin{array}{c}0.00-15.00 \\
(5.75)\end{array}$ & $\begin{array}{c}0.00-16.00 \\
(6.81)\end{array}$ & $\begin{array}{c}0.00-13.00 \\
(5.17)\end{array}$ & 0.484 & NS \\
\hline
\end{tabular}


Table.5 Heavy metal concentration in plant samples collected from both sides of Omti Nala in rainy and winter $\operatorname{season}(\mathrm{n}=17)$

\begin{tabular}{|c|c|c|c|c|c|c|c|c|c|c|c|}
\hline Site & Crop & \multicolumn{5}{|c|}{ Rainy } & \multicolumn{3}{|c|}{ Site } & Crop & \multicolumn{3}{c|}{ Winter } \\
\hline ID & & $\mathbf{N i}$ & $\mathbf{C r}$ & $\mathbf{C d}$ & $\mathbf{P b}$ & $\mathbf{I D}$ & & $\mathbf{N i}$ & $\mathbf{C r}$ & $\mathbf{C d}$ & $\mathbf{P b}$ \\
\hline $\mathbf{S - 8}$ & Rice & 2.70 & 17.95 & 0.50 & 10.00 & 8 & Tomato & 4.35 & 10.40 & 0.75 & 0.95 \\
\hline $\mathbf{S - 1 5}$ & Rice & 3.35 & 12.30 & 0.60 & 1.45 & 9 & Spinach & 6.80 & 9.15 & 1.30 & 17.50 \\
\hline $\mathbf{1 9}$ & Rice & 3.10 & 14.60 & 0.55 & 9.00 & 11 & Brinjal & 8.15 & 16.10 & 1.60 & 16.50 \\
\hline $\mathbf{2 3}$ & Rice & 2.75 & 11.05 & 0.35 & 8.50 & 13 & Brinjal & 15.90 & 29.10 & 2.10 & 32.00 \\
\hline $\mathbf{2 8}$ & Rice & 4.35 & 10.00 & 0.55 & 14.00 & 17 & Brinjal & 11.85 & 19.10 & 1.80 & 22.00 \\
\hline $\mathbf{3 0}$ & Rice & 3.65 & 14.35 & 0.60 & 12.00 & 34 & Wheat & 3.50 & 10.25 & 0.25 & 12.50 \\
\hline $\mathbf{3 5}$ & Rice & 3.45 & 13.95 & 0.35 & 11.50 & 37 & Wheat & 4.10 & 12.45 & 0.30 & 15.50 \\
\hline $\mathbf{3 6}$ & Rice & 3.20 & 10.90 & 0.80 & 12.00 & 40 & Tomato & 7.70 & 13.30 & 0.85 & 12.50 \\
\hline $\mathbf{3 7}$ & Rice & 10.35 & 8.70 & 0.55 & 10.00 & 42 & Sugar beat & 7.15 & 9.65 & 0.80 & 11.00 \\
\hline $\mathbf{4 2}$ & Rice & 3.65 & 7.05 & 0.40 & 11.50 & 43 & Wheat & 3.15 & 7.80 & 0.40 & 14.00 \\
\hline $\mathbf{4 3}$ & Rice & 2.95 & 11.40 & 0.65 & 12.50 & 44 & Wheat & 3.20 & 7.95 & 0.40 & 16.00 \\
\hline $\mathbf{4 5}$ & Rice & 3.55 & 18.70 & 0.45 & 10.00 & 45 & Wheat & 2.90 & 9.00 & 0.30 & 12.50 \\
\hline $\mathbf{5 1}$ & Rice & 6.55 & 10.60 & 0.50 & 11.00 & 51 & Wheat & 1.90 & 7.70 & 0.15 & 10.50 \\
\hline $\mathbf{5 7}$ & Rice & 3.65 & 11.15 & 0.25 & 10.00 & 63 & Wheat & 1.70 & 14.15 & 0.15 & 7.50 \\
\hline $\mathbf{6 3}$ & Rice & 3.80 & 8.20 & 0.70 & 15.50 & 68 & Wheat & 1.70 & 10.15 & 0.15 & 7.50 \\
\hline $\mathbf{6 7}$ & Rice & 5.45 & 7.00 & 0.20 & 13.50 & 75 & Wheat & 2.30 & 8.50 & 0.40 & 16.50 \\
\hline $\mathbf{7 4}$ & Rice & 2.30 & 11.45 & 0.25 & 3.50 & 80 & Spinach & 6.70 & 13.50 & 0.55 & 19.50 \\
\hline Permissible & $\mathbf{6 7 . 0 0}$ & $\mathbf{2 0}$ & $\mathbf{1 . 5 0}$ & $\mathbf{2 . 5 0}$ & & & $\mathbf{6 7 . 0 0}$ & $\mathbf{2 0}$ & $\mathbf{1 . 5 0}$ & $\mathbf{2 . 5 0}$ \\
\hline & limit & & & & & & & & & & \\
\hline
\end{tabular}

EU (2006) (Awasthi 2000)

Table.6 Correlation coefficient between DTPA extractable metals and metals content in crops

\begin{tabular}{|l|c|c|c|c|c|c|c|c|}
\hline \multirow{2}{*}{ Parameters } & \multicolumn{9}{|c|}{ DTPA extractable in soils } & \multicolumn{3}{c|}{ metals in plant } \\
\cline { 2 - 10 } & $\mathbf{N i}$ & $\mathbf{C r}$ & $\mathbf{C d}$ & $\mathbf{P b}$ & $\mathbf{N i}$ & $\mathbf{C r}$ & $\mathbf{C d}$ & $\mathbf{P b}$ \\
\hline DTPA Ni in soil & 1 & & & & & & & \\
\hline DTPA Cr in soil & 0.047 & 1 & & & & & & \\
\hline DTPA Cd in soil & -0.279 & $0.469^{*}$ & 1 & & & & & \\
\hline DTPA Pb in soil & -0.287 & $0.382^{*}$ & $0.974^{* *}$ & 1 & & & & \\
\hline Ni in plant & -0.274 & 0.076 & $0.474^{*}$ & $0.404^{*}$ & 1 & & & \\
\hline Cr in plant & -0.128 & 0.056 & 0.222 & 0.154 & $0.563^{* *}$ & 1 & & \\
\hline Cd in plant & -0.301 & 0.105 & $0.699^{* *}$ & $0.626^{* *}$ & $0.822^{* *}$ & $0.637^{* *}$ & 1 & \\
\hline Pb in plant & -0.184 & 0.305 & 0.335 & 0.204 & $0.726^{* *}$ & $0.502^{* *}$ & $0.701^{* *}$ & 1 \\
\hline *. Correlation is significant at the 0.05 level (2-tailed). & & & & \\
\hline **. Correlation is significant at the 0.01 level (2-tailed). & & & & \\
\hline
\end{tabular}


Table.7 Transfer factor of heavy metals from soil to crops and vegetables grown at Omti Nala

\begin{tabular}{|c|c|c|c|c|}
\hline Crop/vegetables & Ni & Cr & Cd & Pb \\
\hline Rice & 4.3 & 28.5 & 5.6 & 3.6 \\
\hline Rice & 6.2 & 22.8 & 6.7 & 0.5 \\
\hline Rice & 3.5 & 32.4 & 7.9 & 3.8 \\
\hline Rice & 27.5 & 23.5 & 5.0 & 3.4 \\
\hline Rice & 6.8 & 18.5 & 5.0 & 5.8 \\
\hline Rice & 6.1 & 27.1 & 7.5 & 4.4 \\
\hline Rice & 6.1 & 26.3 & 8.8 & 8.0 \\
\hline Rice & 7.2 & 24.8 & 9.1 & 6.2 \\
\hline Rice & 18.1 & 21.5 & 9.8 & 5.6 \\
\hline Rice & 8.6 & 12.4 & 5.6 & 3.8 \\
\hline Rice & 7.5 & 22.3 & 7.6 & 4.4 \\
\hline Rice & 5.9 & 39.0 & 9.0 & 3.6 \\
\hline Rice & 29.8 & 21.2 & 7.1 & 3.4 \\
\hline Rice & 9.9 & 16.4 & 1.7 & 2.4 \\
\hline Rice & 27.1 & 11.5 & 4.4 & 3.4 \\
\hline Rice & 34.1 & 10.1 & 1.4 & 3.1 \\
\hline Rice & 8.8 & 14.1 & 1.6 & 0.7 \\
\hline Tomato & 35.08 & 14.05 & 1.89 & 0.07 \\
\hline Brinjal & $\mathbf{7 5 . 4 6}$ & $\mathbf{1 4 . 2 5}$ & $\mathbf{3 . 0 2}$ & $\mathbf{1 . 2 9}$ \\
\hline Brinjal & $\mathbf{9 3 . 9 2}$ & $\mathbf{2 7 . 4 5}$ & $\mathbf{7 . 3 9}$ & $\mathbf{4 . 9 8}$ \\
\hline Brinjal & $\mathbf{6 8 . 9 0}$ & $\mathbf{2 0 . 9 9}$ & $\mathbf{3 . 6 0}$ & $\mathbf{1 . 8 2}$ \\
\hline Spinach & 29.39 & 8.79 & 4.66 & 7.74 \\
\hline Spinach & 40.96 & 7.77 & 2.48 & 1.33 \\
\hline Wheat & 10.37 & 10.05 & 0.79 & 1.60 \\
\hline Wheat & 12.14 & 8.00 & 0.89 & 1.90 \\
\hline Wheat & 11.62 & 7.18 & 3.92 & 5.19 \\
\hline & & & & \\
\hline
\end{tabular}


Table.8 Relationship of physico-chemical properties with heavy metals in soils in rainy and winter seasons $(n=80+80=160)$

\begin{tabular}{|c|c|c|c|c|c|c|c|c|c|c|c|c|}
\hline \multirow[t]{2}{*}{ parameter } & \multicolumn{2}{|c|}{ pH } & \multicolumn{2}{|c|}{ EC } & \multicolumn{2}{|c|}{ OC } & \multicolumn{2}{|c|}{$\mathrm{Cr}$} & \multicolumn{2}{|c|}{$\mathbf{N i}$} & \multicolumn{2}{|c|}{ Cd } \\
\hline & $\mathbf{R}$ & W & $\mathbf{R}$ & W & $\mathbf{R}$ & $\mathbf{W}$ & $\mathbf{R}$ & W & $\mathbf{R}$ & W & $\mathbf{R}$ & W \\
\hline EC & -0.106 & $-0.601 * *$ & & & & & & & & & & \\
\hline OC & $-0.252 *$ & $-0.356 * *$ & 0.162 & $0.239 *$ & & & & & & & & \\
\hline $\mathrm{Cr}$ & $-0.413 * *$ & $0.304 * *$ & 0.191 & -0.141 & 0.21 & -0.218 & & & & & & \\
\hline $\mathbf{N i}$ & -0.067 & 0.041 & 0.124 & 0.01 & $0.305 * *$ & 0.011 & -0.121 & $0.438 * *$ & & & & \\
\hline Cd & -0.159 & $-0.696 * *$ & 0.172 & $0.366^{* *}$ & $0.279 *$ & $0.333^{* *}$ & 0.134 & -0.094 & $0.817 * *$ & $0.318 * *$ & & \\
\hline $\mathbf{P b}$ & 0.033 & $-0.619 * *$ & 0.089 & $0.420 * *$ & $0.232 *$ & $0.240 *$ & $-.241 *$ & 0.014 & $0.862 * *$ & $0.369 * *$ & $0.810^{* * *}$ & $0.833^{* *}$ \\
\hline
\end{tabular}

*. Correlation is significant at the 0.05 level (2-tailed).

**. Correlation is significant at the 0.01 level (2-tailed). 
Table.9a Factor analysis-results (Rainy season)

\begin{tabular}{|c|c|c|c|}
\hline \multirow{2}{*}{ Attributes } & \multicolumn{2}{|c|}{ Principal Component } & \multirow{2}{*}{ Communalities } \\
\cline { 2 - 4 } & PC1(Ni, Cd, Pb) & $\begin{array}{c}\text { PC2(pH, EC, OC, } \\
\mathbf{C r})\end{array}$ & \\
\hline $\mathbf{p H}$ & 0.006 & $\mathbf{- 0 . 7 4 7}$ & 0.55 \\
\hline $\mathbf{E C}$ & 0.144 & $\mathbf{0 . 4 3}$ & 0.20 \\
\hline $\mathbf{O C}$ & 0.335 & 0.537 & 0.40 \\
\hline $\mathbf{C r}$ & -0.197 & $\mathbf{0 . 8 0 4}$ & 0.68 \\
\hline $\mathbf{N i}$ & $\mathbf{0 . 9 4 7}$ & 0.056 & 0.90 \\
\hline $\mathbf{C d}$ & $\mathbf{0 . 8 8 7}$ & 0.249 & 0.84 \\
\hline $\mathbf{P b}$ & $\mathbf{0 . 9 5 7}$ & -0.086 & 0.92 \\
\hline Eigen values & $\mathbf{2 . 8 3 9}$ & $\mathbf{1 . 6 8 3}$ & Total variance \\
\hline $\begin{array}{c}\text { \% of } \\
\text { Variance }\end{array}$ & $\mathbf{4 0 . 5 6 1}$ & $\mathbf{2 4 . 0 4 9}$ & $\mathbf{( 6 4 . 6 1 \% )}$ \\
\hline
\end{tabular}

Table.9b Factor analysis-results (winter season)

\begin{tabular}{|c|c|c|c|}
\hline \multirow{2}{*}{ Attributes } & \multicolumn{2}{|c|}{ Principal Component } & \multirow{2}{*}{ Communalities } \\
\cline { 2 - 4 } & PC1(pH, EC, OC, Cd, Pb) & $\begin{array}{c}\text { PC2(Cr, } \\
\text { Ni) }\end{array}$ & \\
\hline $\mathbf{p H}$ & -0.866 & 0.245 & 0.81 \\
\hline $\mathbf{E C}$ & 0.661 & -0.182 & 0.47 \\
\hline $\mathbf{O C}$ & 0.495 & -0.253 & 0.30 \\
\hline $\mathbf{C r}$ & -0.211 & 0.803 & 0.68 \\
\hline $\mathbf{N i}$ & 0.235 & 0.838 & 0.75 \\
\hline $\mathbf{C d}$ & 0.887 & 0.193 & 0.82 \\
\hline $\mathbf{P b}$ & 0.856 & 0.303 & 0.82 \\
\hline Eigen values & $\mathbf{3 . 0 5}$ & $\mathbf{1 . 6 3 3}$ & Total variance \\
\hline $\begin{array}{c}\text { \% of } \\
\text { Variance }\end{array}$ & $\mathbf{4 3 . 5 6 9}$ & $\mathbf{2 3 . 3 2 7}$ & $\mathbf{( 6 6 . 8 9 6 \% )}$ \\
\hline
\end{tabular}


Table.10 Clustering analysis and tests of equality of group means in rainy season

\begin{tabular}{|c|c|c|c|c|c|c|c|c|}
\hline Zone & Sites & pH & $\begin{array}{c}\mathrm{EC} \\
\left(\mathrm{dSm}^{-1}\right)\end{array}$ & $\begin{array}{c}\mathrm{OC} \\
\left(\mathrm{gkg}^{-1}\right)\end{array}$ & $\begin{array}{c}\mathrm{Ni} \\
\left(\mathrm{mgkg}^{-1}\right)\end{array}$ & $\begin{array}{c}\mathrm{Cr} \\
\left(\mathrm{mgkg}^{-1}\right)\end{array}$ & $\begin{array}{c}\mathrm{Cd} \\
\left(\mathrm{mgkg}^{-1}\right)\end{array}$ & $\begin{array}{c}\text { Pb } \\
\left(\mathrm{mgkg}^{-1}\right)\end{array}$ \\
\hline 1 & $\begin{array}{l}\text { S-60,S-72,S-62,S-57,S-52,S-56,S-78,S-55,S-77,S-80,S-61,S- } \\
\text { 79,S-63,S-71 }\end{array}$ & 7.92 & 0.16 & 4.97 & 0.72 & 0.24 & 0.15 & 4.36 \\
\hline 2 & $\begin{array}{l}\text { S-64,S-73,S-74,S-59,S-75,S-50,S-51,S-51,S-42,S-48,S-54,S- } \\
53\end{array}$ & 7.91 & 0.1 & 3.91 & 0.65 & 0.26 & 0.13 & 3.66 \\
\hline 3 & S-68,S-70,S-76,S-65,S-67,S-66,S-69,S-58,S-2 & 7.85 & 0.22 & 2.79 & 0.78 & 0.3 & 0.21 & 4.71 \\
\hline 4 & S-3,S-4,S-5,S-1 & 7.16 & 0.3 & 6.07 & 1.15 & 0.6 & 0.4 & 6.74 \\
\hline 5 & S-40,S-41,'S-43,S-44 & 7.94 & 0.13 & 1.35 & 0.5 & 0.29 & 0.09 & 3.07 \\
\hline 6 & $\begin{array}{l}\text { S-31,S-37,S-33,S-46,S-49,S-38,S-27,S-30,S-39,S-45,S-47,S- } \\
32\end{array}$ & 7.9 & 0.14 & 2.64 & 0.49 & 0.42 & 0.06 & 2.26 \\
\hline 7 & S-18,S-20,S-21,S-16,S-25,S-26,S-19,S-24,S-34 & 7.69 & 0.21 & 5.69 & 0.52 & 0.53 & 0.08 & 2.16 \\
\hline 8 & S-6,S-10,S-9,S-15,S-28,S-12,S-11,S-14,S-8 & 7.13 & 0.2 & 4.59 & 0.55 & 0.58 & 0.09 & 2.76 \\
\hline 9 & S-22,S-23,S-17,S-29,S-36,S-7,S-13,S-3 & 7.42 & 0.16 & 3.75 & 0.5 & 0.44 & 0.07 & 2.16 \\
\hline \multicolumn{2}{|r|}{ Mean } & 7.71 & 0.17 & 4.02 & 0.63 & 0.39 & 0.13 & 3.4 \\
\hline \multicolumn{2}{|r|}{$S D$} & 0.39 & 0.14 & 1.33 & 0.19 & 0.21 & 0.1 & 1.32 \\
\hline \multicolumn{2}{|r|}{ Wilks' Lambda } & 0.45 & 0.88 & 0.11 & 0.29 & 0.62 & 0.36 & 0.13 \\
\hline \multicolumn{2}{|r|}{$\boldsymbol{F}$} & 10.7 & 1.18 & 70.4 & 21.7 & 5.45 & 15.8 & 57.4 \\
\hline \multicolumn{2}{|r|}{ P-value } & $* *$ & 0.32 & $* *$ & $* *$ & $* *$ & $* *$ & $* *$ \\
\hline
\end{tabular}


Table.11 Clustering analysis and tests of equality of group means in winter season

\begin{tabular}{|c|c|c|c|c|c|c|c|c|}
\hline Zone & Sites & $\mathbf{p H}$ & EC & OC & $\mathbf{N i}$ & $\mathrm{Cr}$ & Cd & $\mathbf{P b}$ \\
\hline 1 & $\begin{array}{l}\text { S-38,S-46,S-42,S-45,S-47,S-20,S-44,S-48,S-49,S-50,S-34,S-40, S- } \\
37, S-42, S-43\end{array}$ & 6.93 & 0.38 & 6.19 & 1.00 & 0.17 & 0.55 & 10.91 \\
\hline 2 & S-04,S-07,S-14,S-39,S-24,S-29,S-22 & 7.12 & 0.37 & 4.28 & 1.11 & 0.12 & 0.50 & 11.59 \\
\hline 3 & $\mathrm{~S}-02, \mathrm{~S}-03, \mathrm{~S}-28, \mathrm{~S}-25, \mathrm{~S}-23, \mathrm{~S}-27, \mathrm{~S}-32$ & 6.94 & 0.31 & 5.76 & 0.96 & 0.07 & 0.62 & 8.32 \\
\hline 4 & S-35,S-69,S-55,S-67,S-62,S-64,S-36,S-80 & 7.50 & 0.24 & 4.60 & 0.36 & 0.02 & 0.21 & 3.52 \\
\hline 5 & S-65,S-68,S-61,S-59,S-77,S-78,S-76,S-70,S-71,S-75,S-57,S-60 & 8.05 & 0.17 & 3.76 & 1.41 & 0.41 & 0.15 & 3.88 \\
\hline 6 & S-09,S-26,S-10,S-18,S-01,S-19 & 8.00 & 0.22 & 4.99 & 1.35 & 0.21 & 0.17 & 4.44 \\
\hline 7 & S-08,S-31,S-15,S-17,S-6,S-05,S-11,S-12,S-21,S-33 & 7.75 & 0.24 & 3.89 & 1.08 & 0.20 & 0.14 & 3.23 \\
\hline & ANOVA result $\mathrm{F}$ & 17.81 & 4.66 & 26.25 & 15.55 & 2.84 & 31.49 & 202.05 \\
\hline & Sig. & 0.00000 & 0.00046 & 0.00000 & 0.00000 & 0.01534 & 0.00000 & 0.00000 \\
\hline & Mean & 7.51 & 0.27 & 4.69 & 0.97 & 0.16 & 0.3 & 5.98 \\
\hline & SD & 0.5 & 0.13 & 1.98 & 0.59 & 0.24 & 0.25 & 4.41 \\
\hline & Wilks' Lambda & 0.311 & 0.679 & 0.841 & 0.586 & 0.715 & 0.478 & 0.445 \\
\hline & $\mathbf{F}$ & 27.01 & 5.76 & 2.302 & 8.593 & 4.848 & 13.291 & 15.182 \\
\hline & P-value & 0 & 0 & 0.043 & 0 & 0 & 0 & 0 \\
\hline
\end{tabular}


Int.J.Curr.Microbiol.App.Sci (2019) 8(2): 64-90

Fig.1 Location map of study area

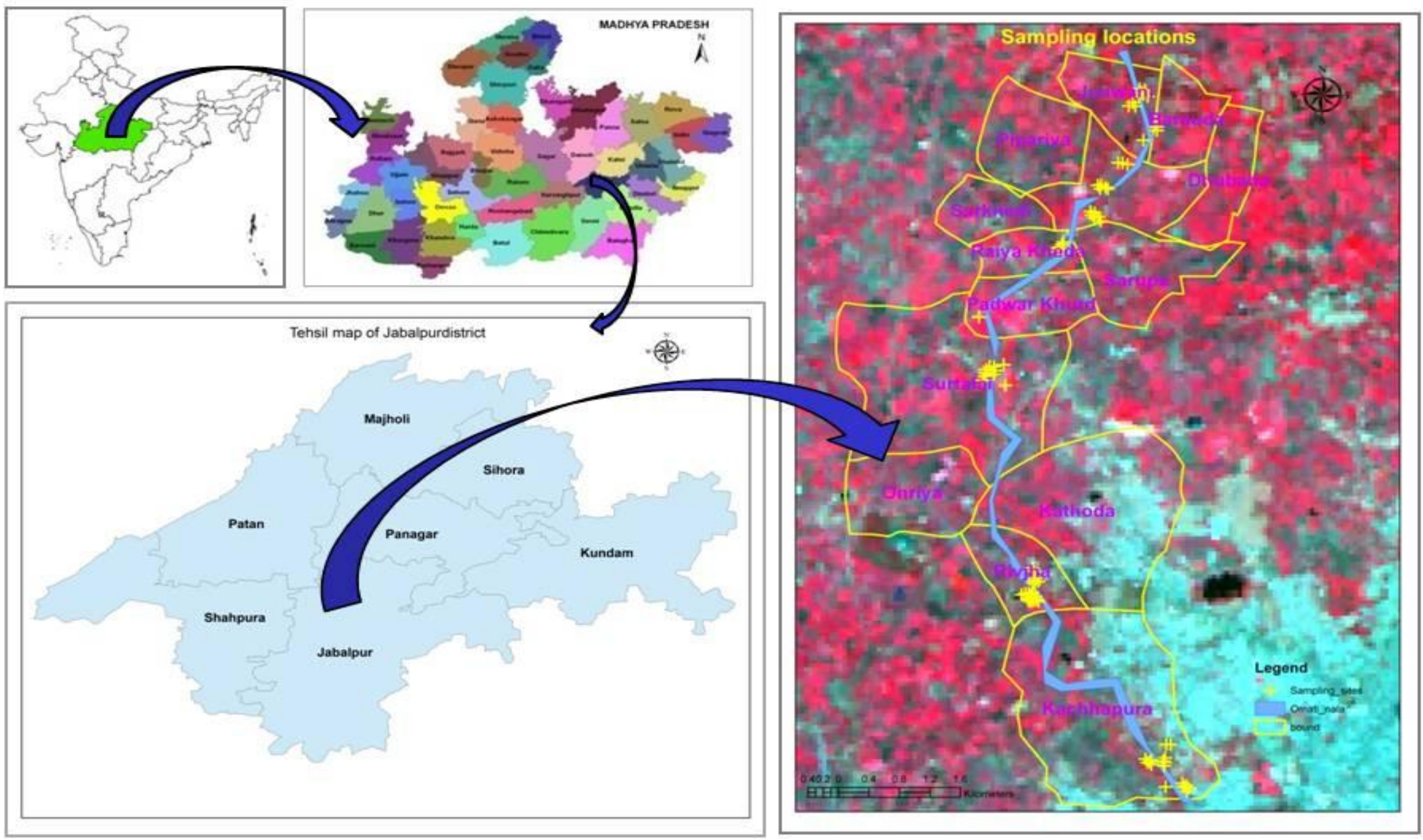


Fig.2 Spatio-temporal maps of physicochemical properties and heavy metals in soil

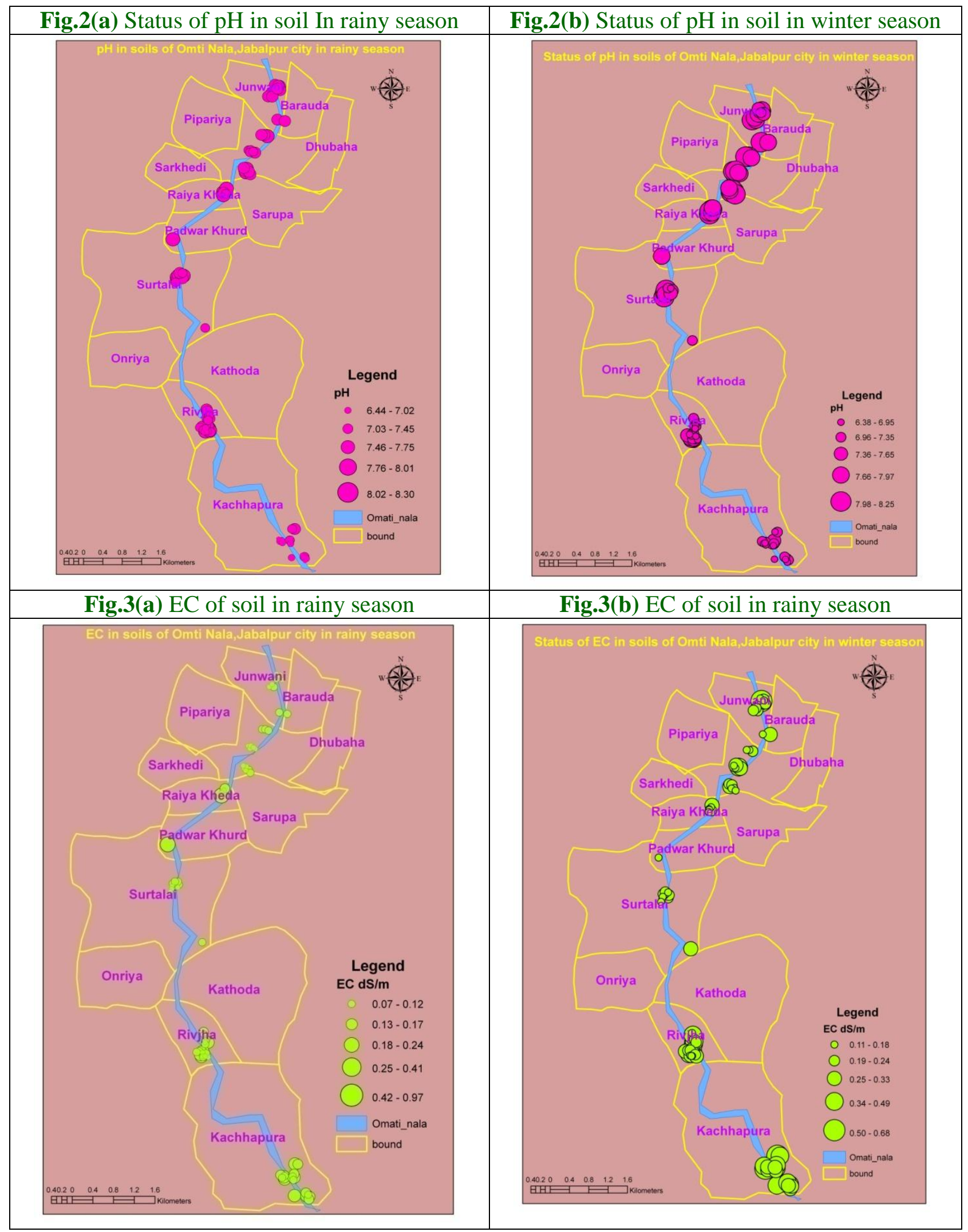




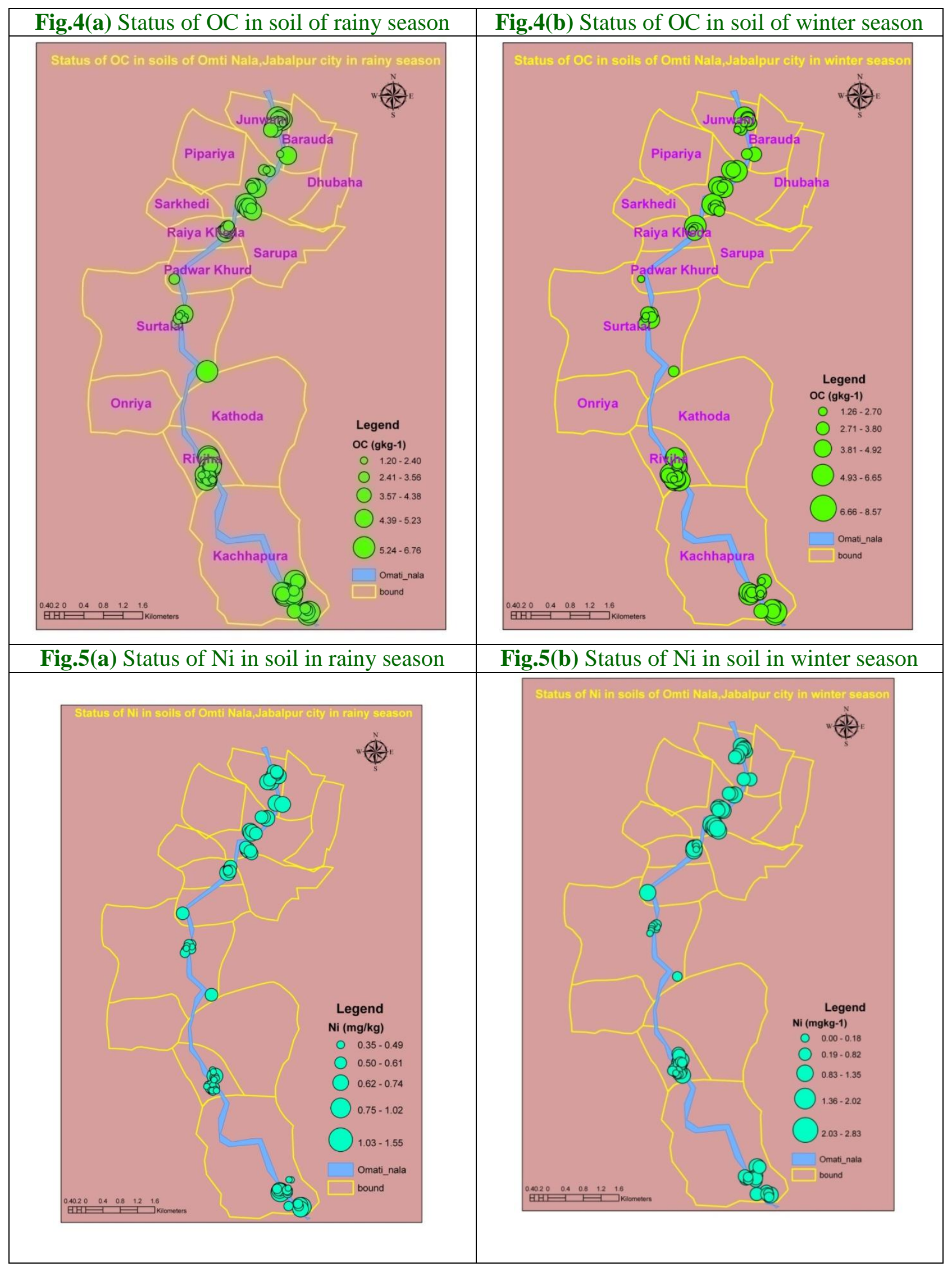




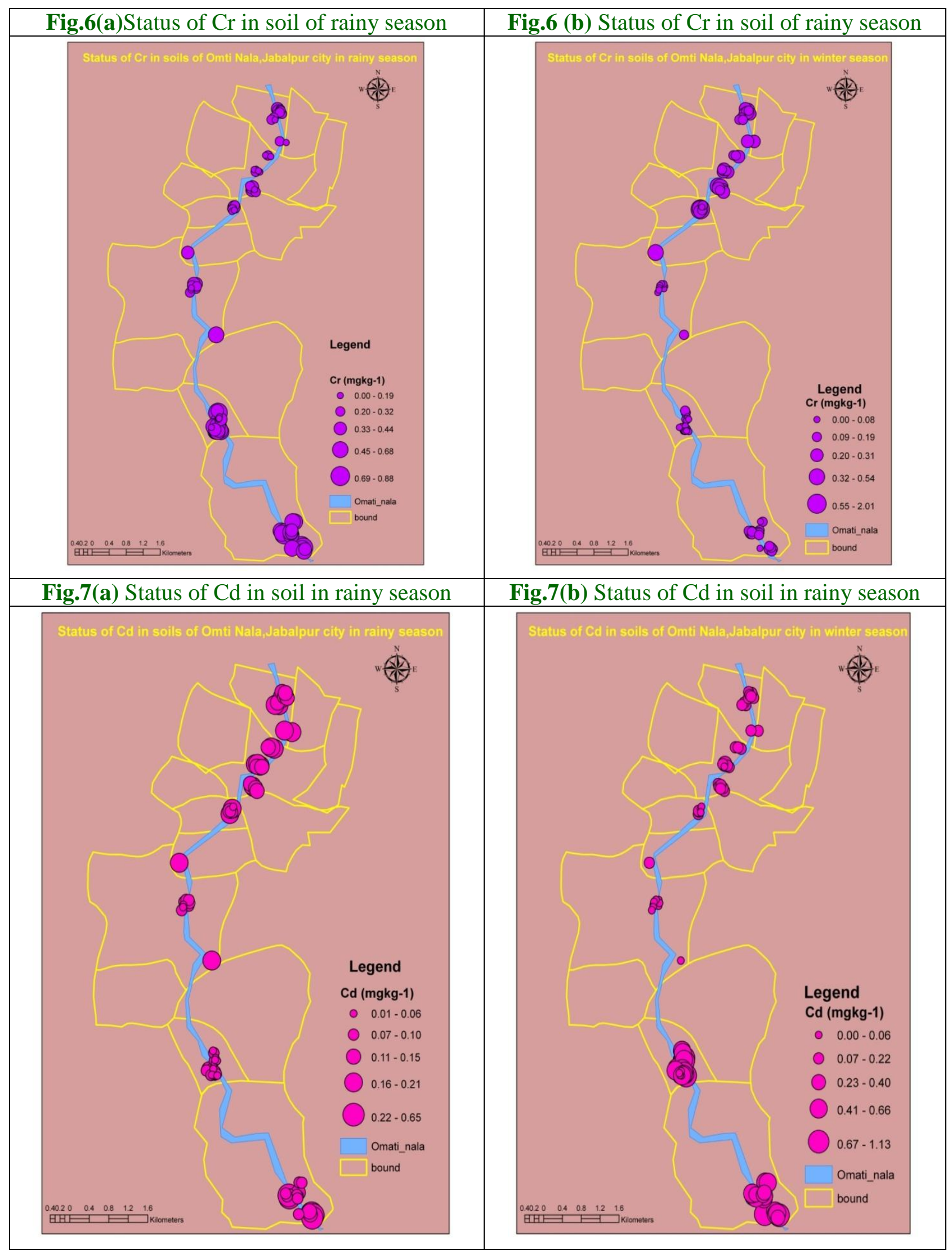




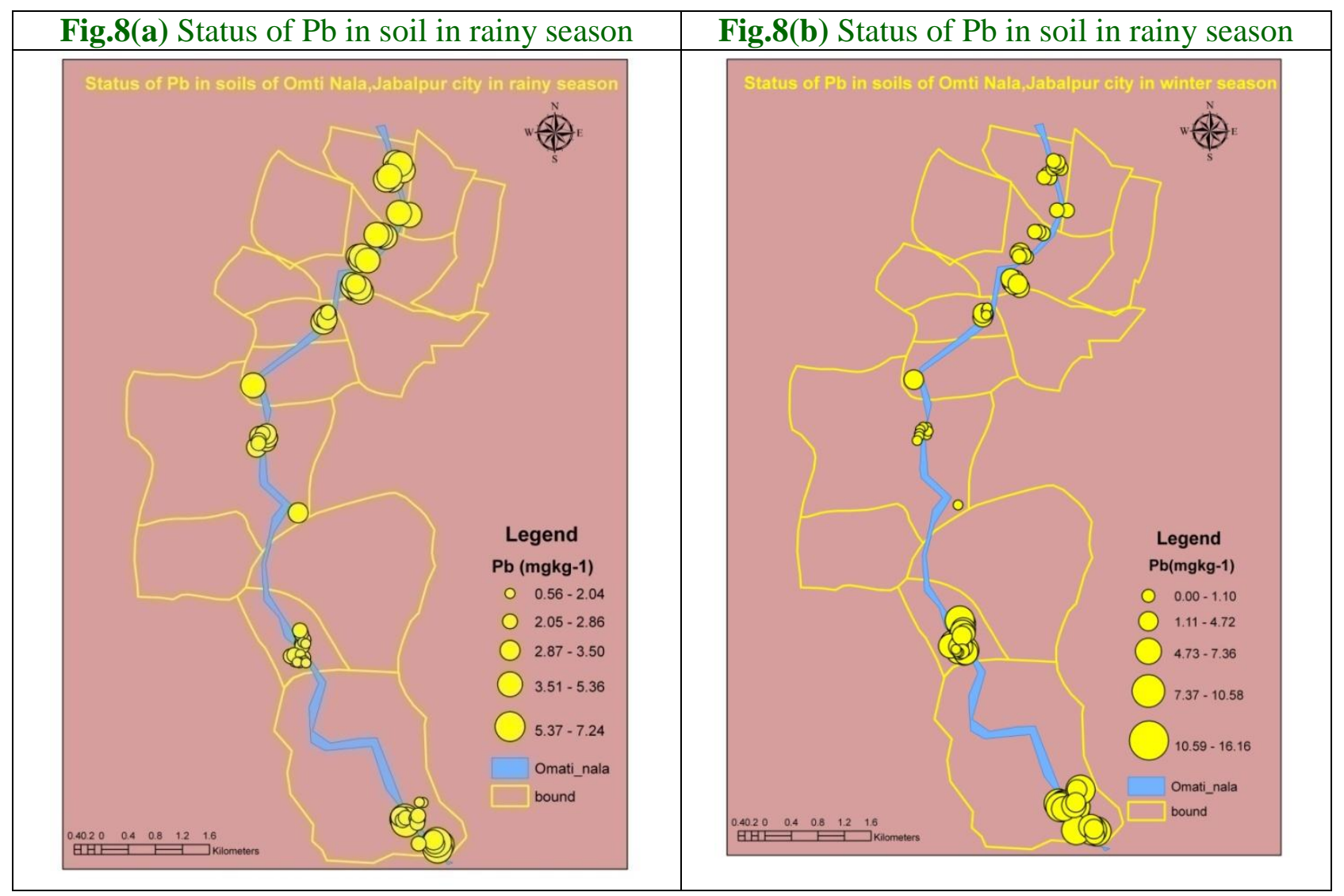

\section{Principal Component Analysis (PCA)}

The variables are correlated with two principal components in which 64.61 and $66.89 \%$ of the total variance in rainy and winter seasons, respectively. The number of significant principal components is selected on the basis of the Kaiser criterion with eigen value higher than 1 (Kaiser, 1960). According to this criterion, only the first two principal components are retained because subsequent eigen values are all less than one. Hence, reduced dimensionality of the descriptor space is two. After varimax orthogonal rotation, two components (factors) are extracted. The first component with 40.56 and $43.56 \%$ of variance comprises $\mathrm{Ni} \mathrm{Cd}$ and $\mathrm{Pb}$ and $\mathrm{pH}, \mathrm{EC}, \mathrm{OC}, \mathrm{Cd}$ and $\mathrm{Pb}$ (bold figures) with high loadings in rainy and winter season respectively.
The second component (PC2) contributes $\mathrm{pH}$, $\mathrm{EC}, \mathrm{OC}$ and $\mathrm{Cr}$ and $\mathrm{Ni}$ and $\mathrm{Cr}$ at 24.04 and $23.32 \%$ total variance. This component seems to be arisen from a different source such as agrochemical products (organic fertilizers) or solid manure.

The obtained results demonstrate that statistical procedures towards classifying the metals as groups in terms of relationship with soil properties and identifying their probable origin in soil. This association strongly suggests that these variables have a similar source. It seems that use of untreated wastewater recently reported at (Qishlaqi et al., 2006) is the main reason for this association. The physicochemical meaning of PC1 also agrees with the correlation coefficient between these variables. Extensive application of wastewater has also resulted in deterioration of the soil quality through 
increase in SOM content facilitating the accumulation of heavy metals in the surface soils in winter season. Soil reaction $(\mathrm{pH})$ is of prime importance in controlling the availability of micronutrients, since it affects directly their solubility as well as activity in the soil environment (Diatta, 2008; Rodriguez et al., 2008; Diatta et al., 2009). Many researchers have used this multivariate tool to identify the most sensitive soil and topographic properties influencing crop production (Jiang and Thelen, 2004; Kaspar et al., 2004; Blanco-Canqui et al., 2006). Similarly results were also reported by Qishlaqi and Moore (2007) (Table 9).

\section{Clustering analysis}

Data explain mean of all checked parameters along with test of equality of group means by Wilk's lambda statistics at $\mathrm{p}<0.05$. Wilk's lambda can also be used to measure potential of parameters before test of factor analysis (FA). It is observed that Wilk's lambda values are small, showing strong discrimination between all values. For grouping of all studied locations, Cluster analysis was done using statistics of agglomeration schedule and by Ward's method as a clustering technique and square Euclidean distance as interval. In rainy season, all sampling sites were grouped into nine groups (to be called zones here) on the basis of spatial similarities among sites and differences among different groups (zones). Clusters are formulated on the basis of variations in the loads of physic chemical properties and heavy metals at each studied location. The results grouped all sampling localities into nine zones and each zone contain following sites: Zone 1 (S-60, S-72, S-62, S-57, S-52, S-56, S-78, S-55, S-77, S80, S-61, S-79, S-63 and S-71), Zone 2 (S-64, S-73, S-74, S-59, S-75, S-50, S-51, S-51, S42, S-48, S-54, S-53), Zone 3 (S-68, S-70, S76, S-65, S-67, S-66, S-69, S-58, S-2), Zone 4 (S-3, S-4, S-5, S-1), Zone 5 (S-40, S-41, S-43,
S-44), Zone 6 (S-31, S-37, S-33, S-46, S-49, S-38, S-27, S-30, S-39, S-45, S-47, S-32), Zone 7(S-18, S-20, S-21, S-16, S-25, S-26, S19, S-24, S-34), Zone 8 (S-6, S-10, S-9, S-15, S-28, S-12, S-11, S-14, S-8) and Zone 9 (S22, S-23, S-17, S-29, S-36, S-7, S-13, S-3).

However, in winter season seven group zone 5,6,7,8 and 9 were found less heavy metals as these were at a reasonable distance from industries and also receives fresh water from nearby running streams and nullahs. Hence stream quality in these localities was better because pollution load decreases from nearby logged areas. Generally, levels of measured parameters were low in this zone in comparison to other zones. This could be related to the dilution and recharging effects. It is assumed that overall pollutant concentration may decrease as suspended particulate materials mostly settle down at the bottom of the streams with decrease in water flow. While in Zone 1, 2, 3 and 4 heavy loads of pollutants were seen as they were containing higher concentrations of metals and other physic-chemical parameters. However In winter season, all sampling sites were grouped into seven groups (to be called zones here) on the basis of spatial similarities among sites and differences among different groups (zones) (Table 10 and 11).

ANOVA result also showed the significant difference between different zone confirm the result of clustering except EC. ANOVA result showed that the zone created using clustering was validated the result of because the all zone were significantly differed for $\mathrm{pH}, \mathrm{EC}$, $\mathrm{OC}$ and heavy mental $\mathrm{Ni}, \mathrm{Cr}, \mathrm{Cd}$ and $\mathrm{Pb}$ confirm with Wilks' lamda value also except $\mathrm{OC}$.

This could be related to the dilution and recharging effects. It is assumed that overall pollutant concentration may decrease as suspended particulate materials mostly settle 
down at the bottom of the streams with decrease in water flow. While in Zone 1, 2, 3, 5 and 6 heavy loads of pollutants were seen as they were containing higher concentrations of metals and other physic-chemical parameters.

However, overall load of $\mathrm{Cd}, \mathrm{Cr}, \mathrm{Ni}$, and $\mathrm{Pb}$ is contributed by lead batteries, industrial effluents, municipal waste, paints and varnishes, discharge from automobile (Temnerud and Bishop, 2005). Lead is found naturally in earth crust in small concentration and it can cause irreversible effects if it is not found in permissible limits (Boman et al., 2000). Similarly results were also reported by Azam et al., (2015).

\section{Spatio-temporal maps generated using GIS}

GIS has the capacity to relate layers of data for the same points in space, combining, analyzing and finally represent it in the map form. Maps represent spatial distribution of $\mathrm{pH}, \mathrm{EC}, \mathrm{OC}$ and heavy metals i.e. $\mathrm{Ni}, \mathrm{Cr}, \mathrm{Cd}$ and $\mathrm{Pb}$ in rainy and winter seasons at all studied sampling sites. Map were present spatio-temporal map of $\mathrm{pH}, \mathrm{EC}, \mathrm{OC}, \mathrm{Ni}, \mathrm{Cr}$, $\mathrm{Cd}$ and $\mathrm{Pb}$ [Figs. 2-8(a\&b)].

\section{References}

Akbar F, Ishaq M, Ihsanullah and Asim SM. 2009. Multivariate statistical analysis of heavy metals pollution in industrial area and its comparison with relatively less polluted area: a case study from the City of Peshawar and District Dir Lower. J. Hazard. Mater. 176, 609616.

Awashthi SK. 2000. Prevention of Food Adulteration Act no 37 of 1954. Central and State Rules as Amended for 1999. Ashoka Law House, New Delhi.

Azam I, Afsheen S, Zia A, Sarwar MK and Iqbal T. 2015. Surface water contamination in Halsi Nala; an assessment and spatial distribution survey using geographical information systems (GIS) approach. Journal of Environmental Chemistry and Ecotoxicology 7(4):37-48.

Bertin $\mathrm{G}$ and Averbeck D. 2006. Cadmium: cellular effects, modifications of biomolecules, modulation of DNA repair and genotoxic consequences Biochimie, 88, 1549-1559.

Bhattacharyya P, Chakraborty A, Chakrabarti K, Tripathy S, Powell MA. 2005. Chromium uptake by rice and accumulation in soil amended with municipal solid waste compost. Chemosphere 60, 1481-1486.

Boman BJ, Wilson PC, Ontermaa EA (2002). Understanding water quality parameters for citrus irrigation and drainage systems, Circular 1406, U.S. Department of Agriculture, Cooperative Extension Service, University of Florida, IFAS, Florida, USA.

Chahal V, Chand P, Nagpal A, Kaur KJ and Pakade YB. 2014. Evaluation of Heavy Metals Contamination and its Genotoxicity in Agricultural Soil of Amritsar, Punjab, India. International Journal of Research in Chemistry and Environment 4(4): 20-28.

Chandra S, Chohan LKS, Murthy RC, Sexana PN, Pande PN, and Gupta SK. 2005. Comparative biomonitoring of leachates from hazardous solid waste of two industries using Allium test, Science Total Environmental. 347, 4652.

Chauhan G. 2014. Toxicity study of metals contamination on vegetables grown in the vicinity of cement factory International Journal of Scientific and Research Publications, (4)11.

De Vries W, Schütze G, Lofts S, Tipping E, Meili M, Römkens PFAM and 
Groenenberg JE. 2005. Calculation of critical loads for cadmium, lead and mercury. Background Document to a Mapping Manual on Critical Loads of Cadmium, Lead and Mercury, Wageningen: Alterra, 43

Ekmekyapar F, Sabudak T And Seren G. 2012. Assessment Of Heavy Metal Contamination In Soil And Wheat (Triticum aestivum L.) Plant Around The Çorlu-Çerkezkoy Highway In Thrace Region Global Nest Journal, 14 (4) Pp 496-504.

European Union 2006. Commission regulation (EC) No. 1881/2006 of 19 December 2006 setting maximum levels for certain contaminants in foodstuffs. Off. J. Eur. Union L. 364, 5-24.

Facchinelli A, Sacchi E and Mallen L. 2001. Multivariate statistical and GIS-based approach toidentify heavy metals sources in soils. Environmental Pollution. 114: 13-324.

Freitas M, Gomes A, Porto G and Fernandes E. 2010. Nickel induces oxidative burst, NF-kappaB activation and interleukin-8 production in human neutrophils, Journal Biology Inorganic Chemistry. 15, 1275-1283.

Gimmler H, Carandang J, Boots A, Reisberg E, Woitke M 2002. Heavy metal content and distribution within a woody plant during and after seven years continuous growth on municipal solid waste (MSW) bottom slag rich in heavy metals. Journal Application Botany, 76: 203-217.

Gowd S. 2010. Assessment of heavy metal contamination in soils at Jajmau (Kanpur) and Unnao industrial areas of the Ganga Plain, Uttar Pradesh, India. Journal of Hazardous Materials. 174: 113-121.

Jackson ML. 1973. Soil Chemical Analysis. Constable Co. Ltd., London.
Jan FA, Ishaq M, Khan S, Ihsanullah I, Ahmad I and Shakirullah M. 2010. A comparative study of human health risks via consumption of food crops grown on wastewater irrigated soil

Janos P,Vavrova J, Herzogova L and Pilarova V. 2010. Effects of inorganic and organic amendments on the mobility (leachability) of heavy metals in contaminated soil: A sequential extraction study, Geoderma, 159, 335341.

Jantschi L, Suciu I, Cosma C, Todica M and Bolboaca SD. 2008. Analysis of soil heavy metal pollution and pattern in Central Transylvania, International journal of molecular science. 9- 434.

Kaiser HF. 1960. The application of electronic computers to factor analysis. Edu. Psychol. Meas., 20: 141-151.

Kar SP, Mandal SK, Saha $\mathrm{T}$ and Kole RK.2008. Assessment of heavy metal pollution in surface water. Indian Journal Environmental Sciences Technology. 5(1): 119-124, Winter.

Karatas M, Dursun S, Guler E, Ozdemir C and Argun ME. 2006. Heavy metal accumulation in wheat plants irrigated by waste water. Cellulose Chemistry And Technology.

Khan S, Rehman S, Khan AZ, Khan MA and Shah T. 2010. Soil and vegetables enrichment with heavy metals from geological sources in Gilgit, northern Pakistan. Ecotoxicol. Environ. Safety 73, 1820-1827.

Lado LR, Hengl T, and Reuter HI. 2008. Heavy metals in European soils: A geostatistical analysis of the FOREGS Geochemical database, Geoderma., 148, 189-199.

Lin YP, Teng TP and Chang TK.2002. Multivariate analysis of soil heavy metal pollution and landscape pattern in Changhua County in Taiwan, 
Landscape Urban Plan, 62, 19-35.

Lindsay WL and Norvell WA. 1978. Development of DTPA soil test for zinc, iron, manganese and copper. Soil Science Society of America Journal, 42: 421-428.

Mahmood A and Malik RN. 2013. Human health risk assessment of heavy metals via consumption of contaminated vegetables collected from different irrigation sources in Lahore, Pakistan. Arabian Journal of Chemistry 7, 9199.

Muhr GR, Datta NP, Subrsmany HS, Leley VK and Dunahue RL. 1965. Soil testing in India. Asia Press, New Delhi.

Nazir R, Khan M, Masab M, Rehman H, Rauf $\mathrm{N}$, Shahab S, Ameer N, Sajed M, Ullah M, Rafeeq M And Shaheen Z. 2015. Accumulation of Heavy Metals $(\mathrm{Ni}, \mathrm{Cu}, \mathrm{Cd}, \mathrm{Cr}, \mathrm{Pb}, \mathrm{Zn}, \mathrm{Fe})$ in the soil, water and plants and analysis of physico-chemical parameters of soil and water Collected from Tanda Dam kohat. Journal of Pharma Science \& Research. 7(3) 89-97.

Nyamangara J and Mzezewa J. 1999. The effects of long-term sewage sludge application on $\mathrm{Zn}, \mathrm{Cu}, \mathrm{Ni}$ and $\mathrm{Pb}$ levels in clay loam soil under pasture grass in Zimbabwe. Agri. Ecosys. Environ., 73: 199-204.

Osibanjo O and Ajayi SO. 1980. Trace metal levels in tree barks as indicators of atmospheric pollution. Envir. Int., 4: 239-244.

Pandey R, Shubhashish K and Pandey J. 2012. Dietary intake of pollutant aerosols via vegetables influenced by atmospheric deposition and wastewater irrigation. Ecotoxicol. Environ. Safety 76,200-208.

Qadir A, Malik RN and Husain SZ 2008. Spatio-temporal variations in water quality of Nullah Aik-tributary of the river Chenab, Pakistan. Environ. Mon. Assess. 140:43-59

Qadir M, Ghafoor A, and Murtaza G. 2000. Cadmium concentration in vegetables grown on urban soils irrigated with untreated municipal sewage. Environ. Dev. Sustainability 2, 13-21.

Qishlaqi A and Moore F. 2007. Statistical Analysis of Accumulation and Sources of Heavy Metals Occurrence in Agricultural Soils of Khoshk River Banks, Shiraz, Iran. AmericanEurasian Journal of Agricultural \& Environmental Science, 2 (5): 565573.

Rana L, Dhankhar R and Chhikara S. 2010. Soil Characteristics affected by long term Application of Sewage Wastewater. Indian Journal Environmental Res. 4(3):513-518.

Sharma S and Prasade FM 2010. Accumulation of Lead and Cadmium in Soil and Vegetable Crops along Major Highways in Agra (India). Journal of Chemistry. 7(4):1174-1183.

Singh A, Sharma RK, Agrawal M and Marshall FM. 2010. Risk assessment of heavy metal toxicity through contaminated vegetables from wastewater irrigated areas in Varanasi, India. Trop. Ecol. 51: 375-387.

Singh A, Sharma RK., Agrawal $M$ and Marshall FM. 2010. Health risk assessment of heavy metals via dietary intake of foodstuffs from the wastewater irrigated site of a dry tropical area of India. Food Chem. Toxicol. 48, 611-619.

Singh KP, Mohon D, Sinha S and Dalwani R. 2004. Impact assessment of treated/untreated wastewater toxicants discharge by sewage treatment plants on health, agricultural and environmental quality in wastewater disposal area. Chemosphere 55, $227-$ 255. 
Tani FH and Barrington S. 2005. Zinc and copper uptake by plants under two transpiration ratios Part I. Wheat (Triticum aestivum L.). Environ. Pollut. 138, 538-547.

Temnerud J, Bishop K (2005). Spatial variation of stream water chemistry in two Swedish Boreal Catchments: Implications for environmental assessment. Environ. Sci. Technol. 39: 1463-1469.

Tiwari KK, Singh NK, Patel MP, Tiwari MR and Rai UN. 2011. Metal contamination of soil and translocation in vegetables growing under industrial wastewater irrigated agricultural field of Vadodara, Gujarat, India. Ecotoxicology and Environmental Safety, 74(6): 16701677.
Walkley A and Black CA. 1934. An examination of Degt-Jreff method for determination soil organic matter and proposal for modification of the chromic acid titration method. Soil Sci. 37: 29-38.

WHO. 2007. Joint FAO/WHO Expert standards program codex Alimentation Commission. Geneva, Switzerland. Available online http://www.who.int (Accessed 10/09/2012).

Zhang F, Yan X, Zeng C, Zhang M, Shrestha S, Devkota LP and Yao T. 2012. Influence of Traffic Activity on Heavy Metal Concentrations of Roadside Farmland Soil in Mountainous Areas. International of Journal Environmental Research. Public Health 9(5): 17151731.

\section{How to cite this article:}

Balram Patel, Y.M. Sharma, G.S. Tagore, G.D. Sharma and Halecha, G. 2019. Heavy Metal Accrual in Soils and Crops Grown in the Peri Urban Areas of Jabalpur District of Madhya Pradesh, India using Geospatial Techniques. Int.J.Curr.Microbiol.App.Sci. 8(02): 64-90. doi: https://doi.org/10.20546/ijcmas.2019.802.010 